University of Louisville

ThinkIR: The University of Louisville's Institutional Repository

Electronic Theses and Dissertations

8-2016

\title{
"A part of, rather than apart from" : Louisville's black arts scene in the mid-twentieth century.
}

Wesley Sawyer Cunningham

Follow this and additional works at: https://ir.library.louisville.edu/etd

Part of the Cultural History Commons, Public History Commons, and the United States History Commons

\section{Recommended Citation}

Cunningham, Wesley Sawyer, "'A part of, rather than apart from" : Louisville's black arts scene in the midtwentieth century." (2016). Electronic Theses and Dissertations. Paper 2555.

https://doi.org/10.18297/etd/2555

This Master's Thesis is brought to you for free and open access by ThinkIR: The University of Louisville's Institutional Repository. It has been accepted for inclusion in Electronic Theses and Dissertations by an authorized administrator of ThinkIR: The University of Louisville's Institutional Repository. This title appears here courtesy of the author, who has retained all other copyrights. For more information, please contact thinkir@louisville.edu. 
"A PART OF, RATHER THAN APART FROM":

LOUISVILLE'S BLACK ARTS SCENE IN THE MID-TWENTIETH CENTURY

By

Wesley Sawyer Cunningham

B.A., Murray State University, 2011

\begin{abstract}
A Thesis
Submitted to the Faculty of the in Partial Fulfillment of the Requirements

for the Degree of
Master of Arts
in History

Department of History

University of Louisville

Louisville, Kentucky
\end{abstract}

College of Arts and Sciences of the University of Louisville

August, 2016 
Copyright 2016 by Wesley Sawyer Cunningham

All rights reserved 

"A PART OF, RATHER THAN APART FROM":

LOUISVILLE'S BLACK ARTS SCENE IN THE MID-TWENTIETH CENTURY

\begin{tabular}{c} 
By \\
Wesley Sawyer Cunningham \\
B.A., Murray State University, 2011 \\
A Thesis Approved on \\
August 5, 2016 \\
by the following Thesis Committee \\
\hline Lara Kelland Thesis Director \\
\hline Tracy K'Meyer
\end{tabular}

Peter Morrin 


\section{DEDICATION}

To my parents

Don and Sue Cunningham

for their endless love and support, patience and understanding, and for keeping their sanity, I didn't make it easy

I hope I have made you proud

\&

Emilee

who has given me her encouragement, her friendship, and her love

It was always you 


\section{ACKNOWLEDGEMENTS}

This thesis owes so much to so many people and without the support, inspiration, and encouragement from countless people, who knows where I would have ended up. If I forget someone, please understand that it is not that I am ungrateful, it is that I am writing this at the end of a grueling couple of weeks that have had me working nonstop to meet this thesis' deadline and I am a little distracted. I hope that my absentmindedness does not offend anyone. The first person I would like to thank is Dr. Duane Bolin. You helped me realize that being a successful student and athlete did not mean that I had to abandon the former. I am not sure if you ever realized the impact you had on my undergraduate career and my subsequent decision to further my decision, but I would like to say thank you.

To all of the professors in the University of Louisville History Department that I have taken classes from, worked under or simply had fun and interesting conversations with in Gottschalk Hall, I now have a completely different understanding of academics (interpret that how you like). A special thanks to a few among those who specifically influenced me as a public historian; Dr. Tracy K'Meyer, who as a second reader provided amazing suggestions and critiques to my thesis and ultimately helped shape it into what it is, Dr. Dan Vivian who eased me into historic preservation and remained patient during what has to be one of the longest National Register nomination processes ever, and to my advisor and committee chair, Dr. Lara Kelland, you have done so much for me during my 
time in grad school that I cannot begin to list it all. From providing coffee to career advice, thank you for everything.

To the two people who keep the UofL History Department functioning, Lee Keeling and Robin Carroll. You allowed me to procrastinate, vent, and relax. Thank you for your book recommendations, your conversations and for keeping me sane (and employed!) Overall, you have helped make my time here enjoyable.

To my fellow graduate students - Jacob Burress, Alex Covington, Hannah O’Daniel, Javier Bonilla, Danny Michael, John Manley, Erin Wotring and Carl Creason thank you for sharing in the learning, the stress, and the fun that is grad school, but most of all, thank you for the friendship.

A huge thanks goes to all of my friends who have kept me from losing my mind these last few years. All of the road trips, shows and crazy weekends helped me keep from getting too overwhelmed. I cannot overstate how important that has been.

Lastly, to my family, thank you. My future in-laws, all of my aunts, uncles, and cousins, you have provided me with an amazing amount of support through all of the years and I am a better person for it. Brandon and Jenny, you all mean the world to me and now I will have even more time to be the fun uncle to those two little dudes! To my parents, your kind words, unconditional love and Amazon gift cards have brought me to this point. I sincerely appreciate all that you have done for me and I cannot say it enough, thank you. To Emilee, your presence in my life has made me a better person. I love you. 


\section{ABSTRACT \\ “A PART OF, RATHER THAN APART FROM”: \\ LOUISVILLE'S BLACK ARTS SCENE IN THE MID-TWENTIETH CENTURY \\ Wesley Sawyer Cunningham}

August 9, 2016

This thesis examines the role that three predominantly black art organizations - Gallery Enterprises, the Louisville Arts Workshop, and the West Side Players - played in Louisville, Kentucky's black community during the mid-twentieth century. Working from the integrated and cooperative nature of the long Black Freedom Struggle in Louisville, Kentucky, local black artists formed integrated organizations around the arts and promoted black identity, inclusivity and creativity through community-building and consciousness-raising. Furthermore, by defining the varying uses of the term "political" in reference to black art, this work shows that the politicization of artwork can best be understood using a spectrum rather than a broad, generalizing definition. The introduction outlines the central arguments of the paper and the existing scholarship it draws from. The second section outlines national movements around black arts. The third section gives a brief history of Louisville's race relations. The fourth section provides a brief history of the separate organizations in Louisville's black arts scene. The fifth and sixth offer a sketch of those organizations' role in community-building and provides examples of their consciousness-raising respectively. With the alternative thesis, there are two podcast episodes that present this information with the use of narration, oral history excerpts and dramatic readings in a way that is meant to appeal to a broad audience. 
TABLE OF CONTENTS

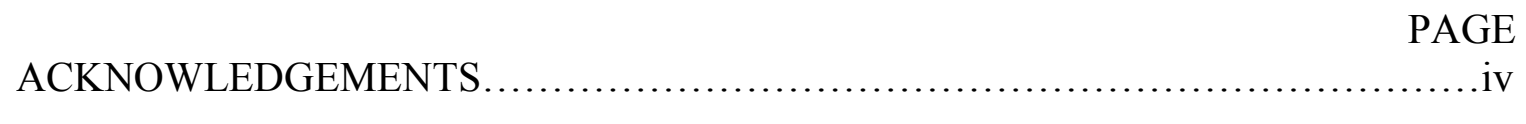

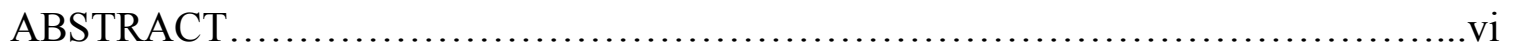

A PART OF, RATHER THAN APART FROM...................................

A HISTORY OF BLACK ARTS NATIONALLY ..................................

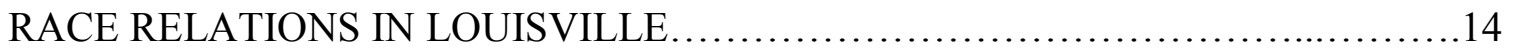

BLACK ARTS IN LOUISVILLE ............................................ 17

ART AND COMMUNITY-BUILDING IN LOUISVILLE.........................25

ARTISTS, THEIR ART AND SOCIAL CONSCIOUSNESS RAISING IN

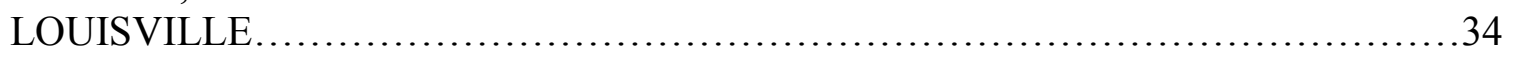

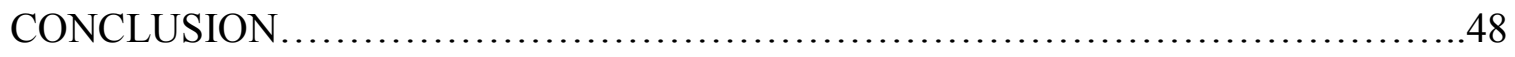

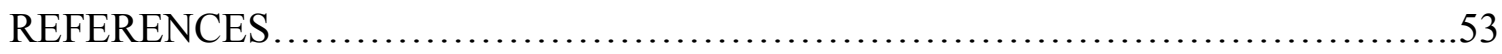

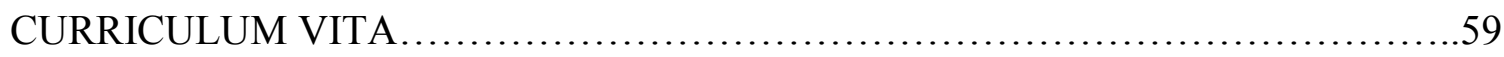




\section{"A PART OF, RATHER THAN APART FROM"}

Cultural production has been an integral aspect of the struggle for African American equality for decades. African Americans have used the visual arts, theater and literature to define a black identity within the United States, engender pride within the black community, and elevate the status of blackness in mainstream white American society. Ultimately, black artists have used their creativity to combat white supremacy. Nationally, African Americans pursued these goals with their work in the Harlem Renaissance of the 1920s and the Black Arts Movement of the mid-1960s, the cultural arm of the Black Power Movement. The Louisville black arts scene from the late fifties to the mid-seventies, although integrated, was made largely of African Americans and operated primarily in the predominantly black neighborhoods. This creative milieu consisted of integrated groups that engaged in anti-racism and promoted the arts in Louisville's black community. An examination of the production and reception of the artwork produced within three organizations in Louisville - Gallery Enterprises, the Louisville Art Workshop, and the West Side Players - as well as the language used by artists about their work reveals that these groups were in fact political, despite frequent assertions by their members to the contrary.

In this thesis, I argue that in the Louisville black arts scene, the actions and artwork of the artists challenged the status quo and thus made political statements. These organizations' aversion to labels like political or activist artists stems from the members' 
view that political meant controversial and that was not their goal. But, political acts exist on a spectrum and cannot be easily defined and compared. Furthermore, the nature of race relations in the city of Louisville contributed to the formation of these groups and the subsequent success of their members. The cooperative and integrationist nature of the black freedom struggle in Louisville and its success encouraged artists to organize around the arts alone. These groups were able to bolster their membership by appealing to professionally trained artists who looked down on what they considered activist art. This black arts scene nurtured the artists' creativity and stimulated self-confidence, which allowed several of the organizations' alumni to go on to greatness in the art world. Through their productions and activities, the art organizations in Louisville were intentional about building an inclusive community around art, promoting a positive black identity, and raising consciousness around social inequalities, all of which should be viewed as political acts.

In order to demonstrate the nature of these art organizations' politicization, one must first understand the different connotations associated with the terminology and how that changes over time. A black artist in the twenties and a black artist in the sixties would logically have different ideas of what constitutes a political act. Therefore, when analyzing what is considered political, one must provide contextualization. For instance, in Louisville, Kentucky during the fifties and sixties, the very act of black men and women forming art organizations was a political act because it promoted black culture, black identity and black autonomy. Similarly, by insisting on maintaining integrated groups, the organizations made a statement about race relations during a tumultuous time in America's history. Whether or not Louisville's artists identified as political artists, 
their subject matter and their actions in that era demonstrate a degree of politicization. Although other artists like Emory Douglas, the Minister of Culture for the Black Panther Party, would appear at a different position on this spectrum of politicization, the Louisville's black art scene was still characteristically political. ${ }^{1}$

Community and community-building were central to the Louisville black arts scene, and the black freedom struggle as a whole, but these terms can carry different meanings. Throughout this paper community refers to different groups characterized by race, geographic location, and identity, none of which are mutually exclusive. Similarly, community-building can represent various actions, often with different intended goals. For example, in the Louisville black arts scene, community-building refers to bringing people who share a similar geographic location together around art by promoting creativity, culture and inclusivity. On a national level, in the black freedom struggle, community-building meant uniting a large group of like-minded individuals around specific beliefs, such as black power, non-violent response to oppression, and support of integrated neighborhoods.

The historiography of black arts and culture in America during the mid-twentieth century has generally focused on art which was produced with a direct, intentional affiliation with the black freedom struggle's efforts to organize, promote black, and build a movement. Historians William L. Van Deburg and Joe Street argued for the importance of the black cultural productions of the Civil Rights Movement and Black Power Movement in promoting a sense of black pride and bolstering "psychological

\footnotetext{
${ }^{1}$ Emory Douglas, Black Panther: The Revolutionary Art of Emory Douglas (New York: Rizzoli Publications, 2007).
} 
liberation," and "psychological freedom." ${ }^{2}$ Charles T. Banner-Haley expands on the outcomes of black cultural productions by including the significant impact that it had on American culture as a whole. His argument echoes the popular civil rights way of thinking that stresses that equality is good for everyone. ${ }^{3}$ James Edward Smethurst, in The Black Arts Movement: Literary Nationalism in the 1960s and 1970s, in addition to stating the importance of culture to the Black Power Movement and black identity as a whole, contends that the national Black Arts Movement was understood differently depending on location and tradition of local communities. However, he also acknowledges that despite local differences, they shared goals with the national struggle for racial justice. Such similarities include the ideologies of the various groups and the development of organizations out of "formal and informal networks...of the old left." Banner-Haley also engages the idea of differences existing throughout the black community as to the role of art and culture, arguing that there was "tension between the idea that artistic renditions of AfroAmerica should be free to depict that culture openly and completely... and the desire of the black middle class to have art stress the positive and uplifting." ${ }^{, 5}$ Claudia Mesch and T.V. Reed both address the role of art in various movements with Reed focusing on American movements and Mesch engaging social justice internationally. When speaking to the role of art and culture in the Civil Rights Movement, Reed points out that the movement and its manifestations changed based on

\footnotetext{
${ }^{2}$ William L. Van Deburg, New Day in Babylon (Chicago: University of Chicago Press, 1992); Joe Street, The Culture War in the Civil Rights Movement (Gainesville, FL: University Press of Florida, 2007).

${ }^{3}$ Charles T. Banner-Haley, The Fruits of Integration: Black Middle-Class Ideology and Culture, 1960-1990 (Jackson, MS: University Press of Mississippi, 1994).

4 James Edward Smethurst, The Black Arts Movement: Literary Nationalism in the 1960s and 1970s (Chapel Hill: The University of North Carolina Press, 2005)

${ }^{5}$ Banner-Haley, The Fruits of Integration, 121.
} 
locality and practice. ${ }^{6}$ Mesch's work is specifically important when stating the nature of how art engages politics. She refers to and expands on philosopher Michel Foucault when she posits that politics, in regards to cultural engagement, consists of actions by a particular social group that affect similar factions and addresses particular problems afflicting them. ${ }^{7}$ This case study in Louisville shows that while individual black artists had differing beliefs about the role of their art as political tools, their artwork and activities illustrate the array of levels of political engagement in culture making. In Louisville, Kentucky, the role of art in social movements and racial politics provides an example of how arts production functioned alongside and complimented political movements for racial and social change. To this end, Louisville black arts organizations provide valuable insight on the role of black arts in the Long Civil Rights Movement. I agree that cultural productions were vital to the psychological freedom of African Americans and I argue that it is important to look at local manifestations of identity production through cultural production. In Louisville, professionally trained artists worked in concert with amateur artists to promote a positive black identity through art and community-building. Additionally, Louisville provides an interesting story of how black arts organizations worked in conjunction, albeit not always intentionally, with national movements and how the politicization of the artwork varies in its intensity through time and from piece to piece. The social justice organizations operating in Louisville supplied a fascinating base of community relations that directly informed the arts organizations. Moreover, by expanding on Mesch's use of political art to include

\footnotetext{
${ }^{6}$ T.V. Reed, The Art of Protest: Culture and Activism from the Civil Rights Movement to the Streets of Seattle (Minneapolis: University of Minnesota Press, 2005). ${ }^{7}$ Claudia Mesch, Art and Politics: A Small History of Art for Social Change since 1945 (New York: I.B. Tauris, 2013).
} 
black artists seeking to be taken seriously as professionally trained artists, it becomes clear that although tactics and subject matter differed between Louisville arts organizations and their members, the existence of such organizations, in addition to much of the artistic themes, was politicized. In Robert L. Douglas' book, Resistance, Insurgence and Identity, he engages the life and art of two artists, poet Mari Evans and painter Nelson Stevens, and in doing so it he outlines a number of aspects that are comparable to the Louisville story. ${ }^{8}$ Douglas' example of Evans, who was actively creating politicized art in the early fifties and whose politicization changed throughout time and intensity, was never directly affiliated with Black Arts Movement organizations even though her art often aligned with their ideologies. Douglas work again parallels to Louisville throughout Nelson Stevens' life. Stevens began a local arts organization without political intentions and helped instigate a local black arts community without explicitly understanding his work as political. Both of these artists were professionally trained and went on to teach art. The resemblance of their stories to Louisville's story is important. It reinforces the idea that politicization changes through time and that political acts need to be understood on spectrum, demonstrates that local black communities were being brought together around the arts without explicit political intention, and it also shows that affiliation with a national arts movement was not necessary to validate politicized art.

Louisville's story demonstrates that there were varying degrees of politicization within one local black arts community, which existed without explicit affiliation with a broader movement. By engaging with the varying uses of the term political as it fits

\footnotetext{
${ }^{8}$ Robert L Douglas, Resistance, Insurgence and Identity: The Art of Mari Evans, Nelson Stevens and the Black Arts Movement (Trenton, NJ: Africa World Press, 2008).
} 
within Louisville's black arts scene, I will show how multiple ways of politicizing art can exist within small organizations. Additionally, I will show that Louisville artists were subscribing to the belief that promoting black identity was vital, and therefore a political act in itself. Tracy K'Meyer shows how in Louisville, the interracial and cooperative nature of the various social justice organizations allowed for multiple coalitions to come together "into a long-term, interconnected struggle." "By demonstrating how the interracial and cooperative attitudes that were prevalent in Louisville go on to inform the creation and subsequent success of the local black arts scene, I am contributing to the understanding of local community-building around black culture.

In Louisville and other places, periodizing black arts goes beyond that of the traditional definition of any of the national arts movements. Jacquelyn Dowd Hall has argued in regards to the Civil Rights Movement that the timeline must be broadened to include post-Depression era politics through the seventies, as well as analysis of the interconnectedness of movements. Not only does she advocate for the expansion of the timeline, but for the increased understanding about what should be considered belonging to the movement. ${ }^{10}$ I borrow her model to frame black arts production in Louisville as moving forwards and backwards through time beyond the more traditional time frame of the Civil Rights Movement. Additionally, I explore how political connotations in artwork from Louisville's black arts scene varies and does not fit into the broad understanding of movement based art nationally, but instead continuously fluctuates along a politicization spectrum.

\footnotetext{
${ }^{9}$ Tracy E. K'Meyer, Civil Rights in the Gateway to the South: Louisville, Kentucky, 19451980 (Lexington, KY: The University Press of Kentucky, 2009). ${ }^{10}$ Jacquelyn Dowd Hall, "The Long Civil Rights Movement and the Political Uses of the Past," The Journal of American History 91 (2005), 1233-1263.
} 


\section{A HISTORY OF BLACK ARTS NATIONALLY}

From the time that the first Africans were brought to North America, they relied on their art and music to portray hope, retain a collective identity, and fuel freedom struggles. Many enslaved African Americans had converted to Christianity and had adapted religious hymns to their "call and response" traditions that remained a part of their African heritage. ${ }^{11}$ Continuing through the antebellum period and on into the Civil War, African American folk songs and spirituals were used to render hope by singing of freedom and "the liberation of souls" while maintaining "semblances of their ancestral communities." 12

Beginning in 1910, in response to Jim Crow laws designed to reinforce white supremacy, and stretching through the 1960s, the National Association for the Advancement of Colored People (NAACP) instituted "a number of cultural campaigns...that included publishing art and literature in its magazine, the Crisis," as well as "protesting degrading images in film and television and lobbying for more positive depictions." 13 The NAACP sought to use black art to not only "change white attitudes" but to also "encourage racial pride among African Americans."14 James

\footnotetext{
${ }^{11}$ Burton W. Peretti, Lift Every Voice: The History of African American Music (Lanham, MD: Rowman and Littlefield Publishers, 2009), 28.

12 Ibid, 30.

13 Jenny Woodley, Art for Equality: The NAACP's Cultural Campaign for Civil Rights (Lexington, KY: University Press of Kentucky, 2014), 3.

${ }^{14}$ Ibid, 42
} 
Weldon Johnson, a poet and the first African American to be named executive secretary of the NAACP, wrote in 1928 that "the problem for the Negro is reaching the plane where it is becoming less a matter of dealing with what he is and more a matter of dealing with what America thinks he is." ${ }^{, 15}$ The overall goal was racial uplift and to create art in hopes of changing the widespread perception of outdated stereotypes of what it meant to be African American.

Also in the early twentieth century, following World War One, a movement began in the Harlem neighborhood of New York, the cultural hub of black America, which has since been named the Harlem Renaissance. Often working alongside the NAACP's cultural campaigns, the Harlem Renaissance was a new group of African American intellectuals and artists who concentrated on "black achievement" with the thought that "inequalities due to race might best be removed when reasonable [white] men saw that black men were thinkers, strivers, doers, and were cultured, like themselves." ${ }^{, 16}$ One of the results was "the birth of a New Negro," a figure who dispelled traditional stereotypes of African Americans being submissive and praised "features of black life that Western culture typically vilified; thus black became beautiful. ${ }^{17}$ Additionally, Langston Hughes argued that it was the African American artists' job to "change through force of his art that old whispering, 'I want to be white,' hidden in the aspirations of his people, to 'Why

\footnotetext{
${ }^{15}$ James Weldon Johnson, The Selected Writings of James Weldon Johnson: Volume II, Social, Political, and Literary Essays, ed. Sondra Kathryn Wilson (New York: Oxford University Press, 1995), 406. Originally published as "Race Prejudice and the Negro Artist," in Harper's Magazine 157 (1928), 769-76.

${ }^{16}$ On NAACP's involvement with Harlem Renaissance look at Woodley, Art for Equality, 2, 8, 10, 31, 36-37, 40, 59-61, 127, 154, 160, 199; Quote from Nathan Irvin Huggins, Harlem Renaissance (New York: Oxford University Press, 1971), 4-5.

${ }^{17}$ Jeffrey B. Ferguson, The Harlem Renaissance: A Brief History with Documents (Boston: Bedford/St. Martin's, 2008), 1-29.
} 
should I want to be white? I am a Negro - and beautiful."' Hughes then went on to further discuss the role of African American artists by saying that "We younger Negro artists who create now intend to express our individual dark-skinned selves without fear or shame. If white people are pleased we are glad. If they are not, it doesn't matter....If colored people are pleased we are glad. If they are not, their displeasure doesn't matter either. We build our temples for tomorrow, strong as we know how, and we stand on top of the mountain, free within ourselves." 18

In the late 1920s, several members of the Harlem Renaissance challenged the NAACP's stance on the purpose of art, stating that "civil rights journals such as The Crisis and Opportunity had forced black art down a narrow path calculated to make political progress and gain mainstream white acceptance, but unsuited to the requirements of open and free artistic development." ${ }^{, 19}$ Their stance was rather than seek white acceptance, they should create art to celebrate black identity. These disagreements represented the dichotomy of black art and how ideas change regarding what was politically necessary. While contributors to the Harlem Renaissance saw that changing white stereotypes was necessary, all of the artists did not see propagandized art, or art that is overtly political on the spectrum, as the way to go about it. Instead the artists sought to change the perceptions by creating quality art that rivaled that which was created by white artists. The idea that by simply creating art, the black artist could contribute to the changing of the white perception was not held by everyone in the

\footnotetext{
${ }^{18}$ Woodley, Art for Equality, 42-43. Woodley quotes George S. Schuyler, "The Negro Art Hokum," Nation 122 (June 16, 1926), reprinted in Mitchell, Within the Circle, p. 51-53. And Langston Hughes, "The Negro Artist and the Racial Mountain," Nation 122(June 28, 1926), reprinted in Mitchell, Within the Circle, 55-59.

19 Ibid, 154-155.
} 
NAACP. In fact, W.E.B. DuBois said himself, "I do not care a damn for any art that is not used for propaganda. ${ }^{, 20}$ Here the beliefs of what constitutes political art varies based on the subtlety of the artwork. The Harlem Renaissance ended in the 1930s as the Great Depression ravaged America economically. Though this era of black artistic production came to a close, the effects that it had on black culture made a lasting impression that would be reinvigorated later in the twentieth century.

A renewed interest in black cultural identity accompanied the rise of the Black Power ideology, which came to social and cultural power in the sixties. ${ }^{21}$ Although organizations such as the Nation of Islam and the Black Panther Party became the public face of the Black Power Movement, "black pride and black self-determination" became a rallying cry that lent itself to a cultural or artistic manifestation. ${ }^{22}$ The cultural arm of the Black Power Movement, known as the Black Arts Movement, began in the mid-1960s. Like its predecessor the Harlem Renaissance, the Black Arts Movement consisted of intellectuals, visual artists, poets, and others, and began in the Harlem neighborhood with the formation of Black Arts Repertory Theater and School (BARTS) by Leroi Jones, who later changed his name to Amiri Baraka. The formation of BARTS, along with the emergence of a large number of black journals and magazines, sparked a nationwide

\footnotetext{
${ }^{20}$ W.E.B. DuBois, "Criteria of Negro Art," in The Harlem Renaissance, Jeffrey B. Ferguson, 160-169. "Criteria of Negro Art" was DuBois' address the NAACP convention in 1926 and published in The Crisis.

${ }^{21}$ For more on the founding of the Black Power Movement look to Peniel E. Joseph, Waiting 'Til the Midnight Hour: A Narrative History of Black Power in America (New York: Henry Holt and Company, 2006."

22 Jeffrey O.G. Ogbar, Black Power: Radical Politics and African American Identity (Baltimore: The Johns Hopkins University Press, 2004), 2.
} 
movement that encouraged black culture and the formation of black institutions. ${ }^{23}$ The Black Arts Movement activists "were generally united by a belief in the need for personal and social transformation of African Americans to determine their own political and cultural destiny. ${ }^{, 24}$ Self-determination was another key feature of the new ideology, and the arts were a cultural intervention for such. Larry Neal, prominent poet, playwright and political activist who was responsible for coining the term "Black Arts Movement," called for "the necessity for black people to define the world in their own terms," meaning that it is the job of the black artist "to speak to the spiritual and cultural needs of black people. ${ }^{, 25}$ Similar to that of the Harlem Renaissance, the culture of the Black Arts Movement rejoiced in everything African American. Van Deburg noted that "the movement raised both individual and group expectations, made black folk feel good about themselves, and steered them away from 'cultural homicide'.,26

Many of the elite intellectuals of the Black Arts Movement looked down on the Harlem Renaissance, claiming them "to be insufficiently political, [and] not actively enough engaged with the concerns of working-class African Americans." ${ }^{, 27}$ This view of what was considered political was drastically different than that of the artists from the

\footnotetext{
23 "Editor's Introduction," in John H. Bracey Jr., Sonia Sanchez and James Smethurst, eds., SOS - Calling All Black People: A Black Arts Movement Reader (Amherst, MA: University of Massachusetts Press, 2014), 7; Lisa Gail Collins, "The Art of Transformation: Parallels in the Black Arts and Feminist Art Movements," in New Thoughts on the Black Arts Movement, ed. Lisa Gail Collins and Margo Natalie Crawford (New Brunswick, NJ: Rutgers University Press, 2008), 275. Approximately "800 black theaters and cultural centers in the United States" opened as a result of BARTS.

${ }^{24}$ Bracey Jr., Sanchez and Smethurst, SOS - Calling All Black People, 1.

${ }^{25}$ Larry Neal, "The Black Arts Movement," in SOS - Calling All Black People, 55. Originally published in The Drama Review 12.4, Black Theatre Issue (Summer 1968). On page 1 of SOS, the editors give Neal credit for coining the term.

${ }^{26}$ Van Deburg, New Day in Babylon, 304.

${ }^{27}$ John H. Bracey Jr., Sonia Sanchez, and James Smethurst, "Editor's Introduction," in sOS-Calling All Black People, 3.
} 
Harlem Renaissance. While the artists and intellectuals of the early twentieth century were considered very political for their time, their methods of advocating for African Americans were seen as inadequate by the much more explicit artists of the Black Power era. The artists of the Black Arts Movement sought to engage directly with the black masses, contrary to how they viewed the "high" culture intellectuals of the Harlem Renaissance. The artists associated with the Black Arts Movement promoted the importance of Black Nationalism while the art from the Harlem Renaissance "had been very much bound to an emulation of whites. ${ }^{28}$ With race relations in America reaching new levels of intensity in the sixties and with the rise of Black Power ideologies, the desire for increased politicization in black artwork should be viewed as an obvious outcome. Although not all black art was meant to be political, when it was created out of the black experience in a racially charged nation, oftentimes the artwork carried with it political undertones, even when that was not the chief intent.

${ }^{28}$ Huggins, Harlem Renaissance, 305. 


\section{RACE RELATIONS IN LOUISVILLE}

Louisville, Kentucky has historically been a distinctive setting for race relations in contrast to both the industrial north and the more rural south. As the Gateway to the South, Louisville celebrated southern heritage while boasting elements of northern progressivism. Louisville was distinctly southern with "separate but unequal parks, schools, and hospitals" for African Americans throughout the city as well as limited access to "downtown restaurants, theaters, and stores," however there was "no organized effort" to challenge the Fifteenth Amendment's assertion that African Americans had the right to vote. Moreover, Louisville earned national praise when it successfully integrated schools with relatively little backlash, although it took an additional three years to integrate the schools' faculties. ${ }^{1}$

Louisville's race relations were shaped by “the presence of liberal-minded whites in unions, in religious organizations, and among civil leaders" which led to the cooperative nature of the movement within the city. ${ }^{2}$ In the years following World War II, Louisville witnessed collaborative efforts by "militant blacks and whites" that aligned the problems of the working-class with racism. ${ }^{3}$ This led to coalitions of labor unions and civil rights activists that fought for equal employment and the desegregation of

\footnotetext{
${ }^{1}$ Tracy E. K'Meyer, "'The Gateway to the South': Regional Identity and the Louisville Civil Rights Movement," Ohio Valley History Vol. 4 No. 1 (2004): 45, 49.

${ }^{2}$ K'Meyer, Civil Rights in the Gateway to the South, 12.

${ }^{3}$ Ibid, 20.
} 
public accommodations. Additionally, Louisville had an interesting religious mix involved in the fight for racial justice. Louisville had "relatively large Catholic and Jewish populations compared to other southern cities" who became involved in promoting interracial cooperation. ${ }^{29}$ Moreover, protestant seminaries within the city began to address "race and social issues" that broke "southern white church solidarity on Jim Crow." ${ }^{, 30}$ Coalitions formed by interfaith groups allied themselves with civil rights causes which helped ensure an interracial cooperation throughout the city. ${ }^{31}$ In addition to labor unions and religious groups, Louisville had white civic leaders who were willing to speak out against segregation. Successful white businessmen such as Dan Byck, Arthur Kling, Harry Schachter, Woodford Axton, and Barry Bingham were known as advocates for racial equality. ${ }^{32}$ The interracial cooperation throughout Louisville would continue to characterize Louisville's' race relations throughout the twentieth century.

During the Black Power era in Louisville, cooperation was again at the forefront of social justice movements. The Black Power ideology in the city meant different things to different groups, and as a result, there was an intertwining narrative of cooperation between black militants, civil rights activists, antipoverty supporters and antiwar advocates. In response to hesitancy and fear by white leaders surrounding the rise of the Black Power philosophy, a "“fight back' campaign” rose in Louisville that "united black

\footnotetext{
${ }^{29}$ Ibid, 8.

${ }^{30}$ Ibid.

${ }^{31}$ Ibid, 21.

32 Tracy E. K'Meyer, "Building Interracial Democracy: The Civil Rights Movement in Louisville, Kentucky, 1945-1956," in Time Longer Than Rope: A Century of African American Activism, 1850-1950, eds. Charles M. Payne and Adam Green (New York: New York University Press, 2003); National Register of Historic Places, Wood F. Axton Hall, Louisville, Jefferson County, Kentucky.
} 
power militants, white leftists, and moderate whites" to battle racism. ${ }^{33}$ Although there were generational divides among the African American community, interracial cooperation continued to be integral to the fight for social justice.

Despite social and political inequalities and racial hatred, Louisville developed a thriving black arts scene. Although urban renewal destroyed the "nationally known" black business district on Walnut Street, it did not prevent the black community from preserving its sense of self, and promoting the arts was one way of doing this. ${ }^{34}$ The interracial cooperation that was visible in the social justice movements throughout the city directly informed the nature of the arts organizations. Due to the constant collaboration between white and black activists in the city, and the apparent success of desegregation in some areas of the city, the arts groups were not determined to make politicization a part of their stated goals. This also helps explain why the organizations were all integrated and intent on remaining so. Because these groups were able to organize solely around the arts, they were able to appeal to a larger demographic of serious artists who might have been hesitant to get involved had intentional politicization been a major principle. As a direct result, several members of Louisville's various arts organizations found success in art.

33 K'Meyer, Civil Rights in the Gateway to the South, 181.

${ }^{34}$ Bob Cunningham, Oral History Interview with Wes Cunningham, Louisville, Kentucky, November 13, 2014. 


\section{BLACK ARTS IN LOUISVILLE}

Before the mid to late fifties, black residents in Louisville had not experienced any real organized arts community. There were some formal opportunities for black artists to study at the Bourgard College of Music and Art that was founded in 1927 and was "the first art college in Louisville for African American children." 38 This began when Caroline Bourgard, a white musician, educator, philanthropist and state director of music, came across an article in the local paper. The article outlined the story of a young man named G.C. Coxe who was spotted sketching a Louisville landmark for a class competition. The story told of "his dream and the absence of art in the studies" at Central High School, the all black school he attended. ${ }^{39}$ She was so moved upon seeing this that she opened the school "to provide quality art instruction for the talented black youngsters

of the city." ${ }^{, 40}$ Additionally, there were various opportunities for proper professional

\footnotetext{
${ }^{38}$ Gerald L. Smith, Karen Cotton McDaniel, and John A. Hardin, eds., The Kentucky African American Encyclopedia (Lexington, KY; The University Press of Kentucky, 2015), 58.

${ }^{39}$ Commentary by Anna Lauderdale Huddleston from, Gloucester Caliman Coxe: A Retrospective: Rags and Wires, Sticks and Pantyhose Too, (Louisville: Allen R. Hite Art Institute and Pan African Studies Department, College of Arts and Sciences, University of Louisville, November 17 - December 15, 1995). Published in conjunction with the exhibition of the same name, shown at the Morris B. Belknap Jr. Gallery, Dario A. Covi Gallery, Louisville, KY.

40 Unknown Author, "Black Artists Note Falling Barriers," The Courier-Journal \& Times, March 16, 1975, H:11; p.20; Paintings by G.C. Coxe: 4 Phases, Fred. F. Bond, Curator and Research Assistant, (Nashville, TN: Carl Van Vechten Gallery of Fine Arts, Fisk University, January 23 - February 13, 1972).
} 
training for African Americans, like the University of Louisville Hite Art Institute that admitted black students after desegregation in 1951 and the Art Center Association, later known as the Louisville School of Art, which had a relationship with the University of Louisville that allowed students to utilize both facilities while receiving an education. ${ }^{41}$ Although there was really no art community in Louisville's West End to nurture creativity for African Americans, some local people recall black professionals painting in their spare time. ${ }^{42}$ Additionally, although there were several opportunities for African American artists to get formal training in the mid-twentieth century, local galleries would not show black artists, no matter how qualified the art was and regardless of the instruction the artist had received. ${ }^{43}$

In 1959, several black artists decided to address that issue by forming Gallery Enterprises. The project began with discussions between students and graduates of the University of Louisville art program, all of whom were recipients of the Hite Art Scholarship offered by the University of Louisville Hite Art Institute beginning in $1946 .{ }^{44}$ Although the school was integrated, black artists often felt left out, with one artist stating

${ }^{41}$ John E. Kleber ed., The Encyclopedia of Louisville (Lexington, KY: The University Press of Kentucky, 2001), 570; "Louisville School of Art Records, 1909-1985: Brief Chronology of the Louisville School of Art," University of Louisville Libraries, Archives and Special Collections, accessed July 7, 2016, https://louisville.edu/library/archives/findingaids/LSA.html

${ }^{42}$ Bob Douglas, Oral History Interview with Wes Cunningham, November 12, 2015. Dr. Douglas explains that when he was a kid there was no art community, but he does recall a local barber on Preston St. painting in his spare time as well as himself and his brothers enjoying drawing.

${ }^{43}$ Bob Douglas Interview.

${ }^{44}$ Bob Douglas, July 16, 2013, "The History of Louisville's African American Artists since 1958: The Louisville Art Workshop: An Evolution of Two Generations of African American Artists," Bob Douglas, artist/scholar, accessed on October 10, 2015, http://bobdouglasart.com/?p=911;“Undergraduate Scholarships and Funding," University of Louisville Hite Art Institute, Department of Fine Arts, accessed July 7, 2016, https://louisville.edu/art/scholarship-information/scholarships.html. 
that "the white culture scene takes place in a social setting and blacks are excluded." 45 The group, not yet adopting their official title, partnered with a local night club, the Brown Derby, which allowed them to "use the back third part of the tavern as a meeting place and small gallery." ${ }^{46}$ This growing collection of local artists, who had begun to gain notoriety with their meetings, transformed their area in the Derby into a space that was entirely their own, eventually hosting the first exhibit there as Gallery Enterprises in 1959.

Gallery Enterprises flourished during its time at the Derby. Comprised of a diverse group, both in terms of race and gender, Gallery Enterprises was constantly growing with interested individuals seeking to become a part of this innovative organization. The original group of aspiring artists from the University included painters Bob Douglas, Bob Carter, Kenneth Victor Young, Bob Thompson and Sam Gilliam. They were soon joined by Fred Bond, an aspiring potter and Anna Bond, who was a poet, G.C. Coxe, the first African American to receive an art degree from the University of Louisville, "highly competent artist" Eugenia Dunn, John Wise, a white theater major, and many others who were simply drawn to "the new atmosphere being generated." 47 The group continuously drew large integrated crowds for their exhibits, which also included poetry readings, intellectual discussions, theatrical readings and music. The "happenings," which is what the exhibits and other intellectual and artistic gatherings

\footnotetext{
45 Joan Kay, "Speaking of People: Art Workshop show at Actors gives sampling of a year's work," The Courier-Journal, January 10, 1971, 101.

${ }^{46}$ Douglas, "A History of Louisville's African American Artists since 1958."

${ }^{47}$ Ibid.
} 
were called, were gaining notoriety so quickly that for one exhibit in 1960, "the Brown Derby was so crowded people clogged the sidewalk."48

The popularity of Gallery Enterprises' exhibitions continued to grow, and with it the artists' individual creativity did too. When the "happenings" grew too big for their original space at the Brown Derby, the owner, John Leake, asked Gallery Enterprises to move to the larger space upstairs in order to accommodate the bar's increased clientele. Eventually, Leake became unsatisfied with that arrangement and informed Gallery Enterprises that they would need to pay rent for the space, even though it was the organization itself that had renovated it. As a result, the group "began meeting at each other's houses for critique and planning shows throughout the community."49 Gallery Enterprises sponsored its last event on August 16, 1961 in Central Park. The citywide “Central Park Happening” was successful on two fronts. One of these was that it bolstered community engagement in the arts by offering professional, amateur and children art contests in addition to various performances. The second was because it made a lasting impression on Louisville with Shakespeare in the Park, an idea that was created at this event, became a regular occurrence in the city, similar to the annual St. James art fair that members of Gallery Enterprises played a role in starting. ${ }^{50}$ Despite this

\footnotetext{
${ }^{48}$ Ibid.

${ }^{49}$ Ibid. Gallery Enterprises "gave Saturday shows at the YMCA and community centers such as Plymouth Settlement House and in church meeting rooms on Sundays."

${ }^{50}$ Ibid. Douglas outlines how the ongoing Shakespeare in the Park is a direct descendent of this happening. Many of those who were integral in Gallery Enterprises were also present when clothesline shows began in St. James Court in 1959 which eventually grew into St. James Art Fair, an internationally known art show in Historic Old Louisville; Merv Aubespin, Oral History Interview with Wes Cunningham, Louisville, KY, November 9, 2015; Bob McKay, "Bonding Together," in Cincinnati Magazine, June 1977, 59-62; Tom Karsell, "Art Show In Central Park: 'They Hold Air,' Housewife-Artist Explains About Use
} 
success, Gallery Enterprises dissolved shortly afterward due to a large number of the group's core participants leaving town; Gilliam moved to D.C. to teach and eventually gained international fame with his art, Dunn started an art department at Philander Smith College in Little Rock, Arkansas, Carter was accepted in the MFA program at Parsons School of Design in New York, and Thompson moved to Provincetown, Massachusetts and eventually to New York and his painting earned him worldwide notoriety. ${ }^{51}$

Although not everyone from Gallery Enterprises gained national fame, those who remained in Louisville created a valuable art scene which was arguably as important as the artwork created by those who left. The most important institution in that scene and movement was the Louisville Art Workshop which rose out of the ashes of Gallery Enterprises. After the disbanding of Gallery Enterprises, and the subsequent move of Ken Young a few years later for a job as a Design Specialist at the Smithsonian Museum, there remained in Louisville only three of the organization's key players; Bond, Coxe and Douglas. ${ }^{52}$ Using Douglas' basement as a studio and meeting space Bond, Douglas and eventually Coxe held frequent discussions about "how to have a more successful art group if the opportunity ever arose again." ${ }^{, 53}$ Acknowledging that for their organization to function properly they "must have complete control over their gallery space" and "over their own means of communicating their goals, intentions and their achievements," Bond

of the Pottery," the Courier-Journal, August 21, 1961, 13. The article explains that the festival featured paintings, sculpture, music, drama, and poetry.

${ }^{51}$ Douglas, "The History of Louisville's African American Artists since 1958."

52 Sarah Lansdale, "Kenneth Young Homecoming at Workshop," The Courier-Journal, December 14, 1969, 122. Kenneth Victor Young moved to Washington D.C. in 1963 and became an exhibitions designer for the Smithsonian Institution.

53 Douglas, "The History of Louisville's African American Artists since 1958." 
agreed to "get a group moving again if a permanent setting could be found." ${ }^{54}$ Although in the intermediate years they continued to exhibit where permitted, albeit infrequently, it was not until 1966 that a permanent organization became a possibility.

In 1966, Fred and Anna Bond moved their family into a vacant former grocery store at 3531 Del Park Terrace and they paid the rent with money they had been saving for a house.$^{55}$ This location served as the living quarters for the Bond family as well as the studio and gallery space for the Louisville Art Workshop. The Bonds were the "catalysts who kept the Workshop together" with Fred as director and Anna as the person who "made the Workshop a home" with her poetry, "fine cooking and words of wisdom. ${ }^{, 56}$ Like its predecessor Gallery Enterprises, the Workshop was a very diverse group that included members of different races and genders. In addition to the Bonds, Coxe and Douglas, some of members included aspiring painters Mervin Aubespin, James High, Anna Huddleston as well as white artists Margaret Tyddings, Laura Furlong and Robin Logsdon. ${ }^{57}$ Adding to the "New York SoHo" feel of the Workshop, the organization included theater, dancers, musicians and literary artists, including a white doctor and novelist named David Collins. ${ }^{58}$

The Louisville Art Workshop operated in Louisville for a little over a decade. Ed Hamilton, who became director of the Workshop around 1975, remembered that

\footnotetext{
54 Douglas, "The History of Louisville's African American Artists since 1958."; Joan Kay, "Speaking of People."

55 Joan Kay, "Speaking of People."

${ }^{56}$ Ed Hamilton, The Birth of an Artist: A Journey of Discovery (Louisville: Chicago Spectrum Press, 2006), 44.

57 Douglas, "The History of Louisville's African American Artists since 1958."

${ }^{58}$ Hamilton, The Birth of an Artist, 44; Douglas, "The History of Louisville's African American Artists since 1958."
} 
"between ' 75 and ' 77 we were on the downstroke." ${ }^{59}$ There were several factors that played a part in the organization ceasing to exist. The Bond family moved to Cincinnati where Fred became the Director of the Cincinnati Arts Consortium in 1977, Bob Douglas had moved to Iowa to pursue a PhD in American Studies with a specialty in African and African American Art History and Culture, and persistent financial issues all culminated to a point where the Workshop "just fizzled on out." ${ }^{60}$ Throughout its existence, the Workshop held classes, workshops, gallery shows, and overall played a large part in bringing arts and culture to the predominantly black West End of Louisville.

In 1967, another art group emerged in Louisville, the West Side Players, only this organization utilized performance art. The West Side Players were an integrated theater group of high school students, most of whom were black, around the Louisville area. They began under the direction of VISTA volunteer Carroll Schempp, a white man from Baltimore. They used a multitude of techniques to present their art such as full-length plays, short skits, improvisational pieces, poetry reading and song and covered topics such as "racial injustice, juvenile delinquency, [and] public health." ${ }^{61}$ Like the Louisville Art Workshop, the West Side Players was integrated and focused on education and consciousness raising.

The West Side Players was initiated to address the lacking cultural opportunities for black students in Louisville. Martina Nichols Kunnecke, a former member of the West Side Players, recalls that "it gave the opportunity for African American children to

\footnotetext{
${ }^{59}$ Ed Hamilton, Oral History Interview with Wes Cunningham, Louisville, KY, April 11, 2016.

${ }^{60}$ McKay, "Bonding Together."; Hamilton Interview; "Black Artists Note Falling Barriers"; Quote from Hamilton Interview.

${ }^{61}$ F.W. Woolsey, "Say it with Theater," in The Courier-Journal Magazine, January 25, 1970, p.26. VISTA stands for Volunteers in Service to America.
} 
act and be able to tell a story and we did a lot of, what we called social drama." ${ }^{, 2}$ The Players traveled throughout Louisville and the surrounding areas and were known for bringing controversial plays, skits and discussions on race to regions that were often unaccustomed to such dialogues. ${ }^{63}$ The West Side Players, who were still in existence ten years later, gained their reputation throughout the years by performing well-known plays such as "In White America," by Martin Duberman that analyzes the black experience in this country from slavery through desegregation of schools, but also acted out pieces that were wholly original. ${ }^{64}$ The innovative and provocative methods that the West Side Players used allowed them to raise awareness of racial disparities in America while promoting thoughtful discussions that advocated for integration and equality.

\footnotetext{
62 Martina Nichols Kunnecke, Oral History Interview with Wes Cunningham, Louisville, KY, April 19, 2016.

${ }^{63}$ David McGinty, "Play Pries at Racial Prejudice," The Louisville Times, n.d. 1969. Discusses a performance in Bullitt County that caused debates; Woolsey, "Say it with Theater." Discusses a moment when a member of the audience from a Lexington performance had a revelation saying to one of the performers, "you are the first Negro person I've seen as a person and not as a Negro."

${ }^{64}$ Martin Duberman was a white historian who wrote "In White America" using historical documents. He sought to write a Black history because it was so often left out of the larger narrative and he presented it on stage because he "wanted to combine the evocative power of the spoken word with the confirming power of historical fact." Martin B. Duberman, In White America: A Documentary Play (New York: Samuel French, Inc, 1964), accessed May 23, 2016, Google eBook, https://books.google.com/books?id=8Uv7z7yWCjMC\&printsec=frontcover\#v=onepage \& $q \& f=f a l s e$. Quote from the Preface written by the author on January 12, 1964.
} 


\section{ART AND COMMUNITY-BUILDING IN LOUISVILLE}

The role of art in Louisville's black community was very important throughout the long Civil Rights Movement. Establishing a black identity through the arts is essential because the African American experience has been one of violence, misuse, and humiliation so subsequently their history has frequently been "simplif(ied), appropriate(d), and contain(ed)." ${ }^{, 65}$ Merv Aubespin, when asked about art's importance, stated that art gave "intellectuals a platform to write, artists a platform to do art, gave musicians a platform to play, and during the Civil Rights Movement, all of those things became our way of stating our purpose of how we wanted America to look and be." He continued "We, as African Americans have always wanted to be a part of, rather than apart from, and we've always figured to be a part of, you have to accept me and the gifts I bring...culture makes America what it is. ${ }^{, 66}$ Similarly, Elmer Lucille Allen, the first African American chemist at Brown-Forman and who became active in the arts later in life, said that "arts are vital to any group of people because it becomes a legacy" and that "we have to recognize all ethnic groups" because art "represents your culture."67

\footnotetext{
${ }^{65}$ Hall, "The Long Civil Rights Movement and the Political Uses of the Past," 1235. ${ }^{66}$ Aubespin, Interview with Wes Cunningham.

67 Elmer Lucille Allen, "Biography of Elmer Lucille Allen," emailed to Wes Cunningham on April 2, 2016 and last updated on April 2, 2016; Elmer Lucille Allen, Oral History Interview with Wes Cunningham, Louisville, KY, April 4, 2016.
} 
Establishing an identity and promoting a culture that one can be proud of is essential for the black community.

Through their organizational programming, these art groups focused on the idea of community building. The community that these groups were tending to was not only the black community or a community of artists who were seeking places to show their art, instead, these organizations were seeking to build and unite an integrated group of people around a culture that celebrates and nurtures an individual's identity. In addition to promoting a greater community of cultured egalitarians these organizations sought to provide an art education and appreciation to the West End neighborhoods which many of their members grew up without. Martina Nichols Kunnecke stated that black artists faced more struggles growing up and gaining legitimacy so "they felt social responsibility to help children express themselves, to feel good about themselves, so besides being artists they felt they had a social mission. ${ }^{.68}$ In recent years Ms. Kunnecke has seen the West End communities dissipate and the buildings crumble, but she said that if the artists from the sixties were around, they "would've said 'wait a minute, our communities are important,' they had a sense of a broader vision that included everybody." ${ }^{\prime 69}$

The Louisville Art Workshop especially held community-building as one of its main goals. Fred Bond wrote that "the particular uniqueness of the Workshop was that it provided community resident black artists... with a cultural base, and more importantly, a community cultural identity as vital resource persons. In its development, the Louisville Art Workshop ha[d] become an important rallying point for the black community, and a

${ }^{68}$ Kunnecke, Interview with Wes Cunningham.

69 Ibid. 
source of community strength and, future growth." ${ }^{, 70}$ Additionally, he insisted that their main goal was to serve "the community as artists." citizens who were interested in learning art and it provided lesson plans for schools that worked in conjunction with some of its exhibits. ${ }^{72}$ During his time at the Workshop, Hamilton stated that he learned "so much about art affected a community.", ${ }^{, 3}$ Having a space that promotes creativity and education is valuable for a community and as a result the Workshop thrived for years.

The emphasis that these organizations placed on integration was one of the most prominent illustrations of community-building. Gallery Enterprise was integrated and encouraged people to join discussions at their impromptu "happenings" at the Derby. Although the Louisville Art Workshop was "not a social-service agency or a group to promote race relations," Ed Hamilton recalled that "it didn't matter if you were white or black or Chinese or whatever, it was a diverse place to come and that's what was the beauty." ${ }^{74}$ Similarly, Bob Douglas stated that the Workshop "remained integrated and proud of it." ${ }^{, 75}$ The West Side Players, which was also integrated, was the group that most deliberately challenged segregation and racial inequalities during their productions. Their objectives were "artistic endeavor and community involvement," and they would often get mixed reactions from the audience by tackling subjects such as interracial dating. ${ }^{76}$

\footnotetext{
${ }^{70}$ Paintings by G.C. Coxe.

${ }^{71}$ Kay, "Speaking of People."

${ }^{72}$ Ibid.

${ }^{73}$ Hamilton Interview.

${ }^{74}$ Kay, "Speaking of People."; Hamilton Interview.

${ }^{75}$ Douglas, "The History of Louisville's African American Artists since 1958."

${ }^{76}$ Quote from the program for "Ceremonies in Dark Old Men," by Lonne Elder III, performed by the West Side Players, May $12^{\text {th }}$ and $13^{\text {th }}, 1972$, at The Women's Club, Louisville, KY, Sponsored by Kentucky Arts Commission, the Greater Louisville Fund for
} 
They wanted to promote the idea of integration by facilitating discussions among various communities. They wanted to get people thinking and even if they could make just a small degree of change then it would all be worth it. ${ }^{77}$ Community solidarity was imperative to gain any ground toward equality, and promoting this through the arts was necessary.

In Louisville, the West End Community Council (WECC), a very vocal and active civil rights group, sought to advance race relations with the purpose of promoting an interracial community, and holding an annual Arts and Talent Festival in the West End was one method they used to try to achieve that. ${ }^{78}$ Similar to national trends, members of social justice groups and cultural organizations overlapped in Louisville. ${ }^{79}$ In 1963, several West End residents got together to form WECC with the purpose of "maintaining a racially diverse neighborhood by discouraging white flight. ${ }^{" 80}$ Among those involved were Anne and Carl Braden, a Louisville couple who had a long history of fighting for racial equality in the South, most notably as integral members of the Southern Conference Educational Fund (SCEF). They gained fame throughout the Civil Rights Movement in 1954 when they bought an African American family a house in a white neighborhood in Louisville which led to horrific acts of racism ending in the house being

the Arts, and National Endowment for the Arts; Kunnecke Interview, she recalled that "people were outraged" with them in Bullitt County for their skit on interracial dating.

${ }^{77}$ Office of Economic Opportunity, unnamed report on the West Side Players in Louisville, copy is in the author's possession. The presentation that is being referred to occurred at a special presentation at Actor's theater in August of 1969.

${ }^{78}$ Program for second annual Arts and Talent Festival sponsored by the West End Community Council.

${ }^{79}$ Smethurst, The Black Arts Movement, 319-320. Smethurst shows that often Black intellectuals involved in the Black Arts Movement often worked a great deal with groups like SNCC and CORE.

${ }^{80}$ Mervin Aubespin, Kenneth Clay and J. Blaine Hudson, Two Centuries of Black Louisville: A Photographic History (Louisville; Butler Books, 2011), 197. 
bombed. The Braden's were then tried for sedition and subsequently became pariahs in their city. ${ }^{81}$ WECC, in 1965, decided to put together the first "Fine Arts Festival" in the West End whose purpose was "to bring people together." ${ }^{82}$ The first festival was held in Shawnee Park and was open to anyone because the proposal was meant to unite people, "not necessarily to promote West End talent.." ${ }^{\wedge 3}$ The event featured musical performances, dance performances, poetry readings, art exhibits and theater performances. ${ }^{84}$ WECC's human relations committee deemed that the "main objective of getting members of the West End Community together in a community endeavor was achieved" although there were points that could have been improved upon. ${ }^{85}$

The Louisville Arts and Talents Festival became an annual staple in the West End for the next few years and, after the first Festival, WECC began producing art digests to compliment the Festival experience. ${ }^{86}$ WECC teamed up with Bob Douglas and the Louisville Art Workshop who helped with the organization and the printing and designing of the publications (using a press that in the spirit of solidarity was lent for the purpose by SCEF). ${ }^{87}$ Maintaining the goal of a unified city, the Festival continued to cater to both the white and black communities, even drawing prize money donations from

\footnotetext{
${ }^{81}$ Catherine Fosl, Subversive Southerner: Anne Braden and the Struggle for Racial Justice in the Cold War South (Lexington, KY: University Press of Kentucky, 2006).

82 Minutes from WECC human relations committee, May 18, 1965, in box 1, file 8, West End Community Council Papers, State Historical Society of Wisconsin, Madison, WI.

${ }^{83}$ Minutes from WECC human relations committee, May 18, 1965.

${ }^{84}$ Program for the first annual West End Arts and Talent Festival, July 1965, box 3, file 18, WECC Papers.

${ }^{85}$ Minutes from WECC human relations committee, July 6, 1965, in box 1 , file 8 , WECC Papers; Minutes from WECC human relations committee, June 22, 1965, in box 1, file 8 , WECC Papers. Quote came from the minutes from July 6.

${ }^{86}$ There is no reference to any Arts and Talents festivals after 1969.

${ }^{87}$ West End Community Council Arts and Talents Festival 1967 Literary Digest; Douglas, "A History of Louisville's African American Artists since 1958."
} 
both the Courier-Journal, the City's mostly white newspaper, and the Defender, the paper that catered to the black community ${ }^{88}$ By holding the festivals in the West End, WECC was sending a message to the city that not only could the African American communities produce serious art, but also that the West End, the predominantly black area of town, was a nice and safe place in which to live. By encouraging the participation of both white and black artists, such as the Workshop and the West Side Players, WECC was seeking to bring the city together through collective creativity and cultural diversity. In addition to the positive light in which the festivals were casting the West End, the digests circulated widely throughout the city with as many as 1500 copies being printed. ${ }^{89}$ These festivals demonstrated that the arts could unite the city. These gatherings were used to further the agenda of promoting the West End, validating the artistic abilities of Louisville's black residents, and building a community where cultures could be shared and the struggle could be voiced.

Although events like the Louisville Art Workshop's exhibits and the festivals were a success, the integrated nature of the groups and their racially themed productions were not well received by everyone. Martina Nichols Kunnecke remembered that after a performance in Lexington, Kentucky when she was fifteen or sixteen, a crowd gathered and were "screaming nigger up at us;" that was the first time that she had ever been called that. ${ }^{90}$ After the release of the 1967 Literary Digest that accompanied the WECC Arts and Talents Festival, many Louisvillians felt it necessary to speak out with their

\footnotetext{
${ }^{88}$ Minutes from WECC human relations committee, May 8,1967 , in box 1 , file 8 , WECC Papers.

${ }^{89}$ Minutes from WECC human relations committee, June 17, 1968, in box 1 , file 8 , WECC Papers.

${ }^{90}$ Kunnecke Interview.
} 
opinions of the pieces included in the publication. One opinion piece said that the digest was "filled with nothing but "off-beat filthy trash, full of far-left innuendos on such subjects as Appalachia, Vietnam, the 'pill', poverty, urban renewal, white hate, etc."'91 There were so many responses to that digest in particular that Fred Bond and David M. Collins, the secretary of the Art Workshop, wrote back in response stating that "the stories, essays, and poems which some people have found 'shocking' were therefore drawn from all sectors of the community, because the purpose of the festival was to display the cultural resources of the entire community. The Digest does this.. ${ }^{92}$ The negative responses demonstrated that the organizations were accomplishing their goals of reaching a large demographic that extended outside of the predominantly black West End and that their messages had indeed struck a nerve. The very fact that people were reacting with such hostility showed that the art was effective in making people confront racism. Integrated cultural groups addressing racial issues is a form of consciousness raising and thus political in nature. The passionate anger that various people voiced in response to the artwork is evidence that their work was necessary if there was any hope of change and building an integrated community.

Promoting African American culture was vital to Louisville's black community in the West End, but there were no stores where black men and women could go to celebrate all aspects of black culture until 1967, when Ken Clay opened the Corner of Jazz. Clay is a lifelong social justice advocate in addition to a promoter and participant in

\footnotetext{
${ }^{91}$ Edwin T. Crumpton, "West End Art Festival," letter to the editor for The CourierJournal, 1967.

${ }^{92}$ Fred F. Bond and David M. Collins, "The Festival's Literary Digest," letter to the editor for The Courier-Journal, October 11, 1967.
} 
the Louisville black arts scene. ${ }^{93}$ The Corner of Jazz was opened at $28^{\text {th }}$ and Greenwood, right in the heart of the black business district. The shop was for people who were interested in all aspects of black culture as a place to purchase African art, memorabilia, jazz records, but also where intellectuals could meet and discuss the social and political issues of the day. ${ }^{94}$ This was reminiscent of the spaces that existed in the major cities in America, like New York and Chicago, where black intellectuals exchanged ideas about the advancement of African American life in America. The Corner of Jazz was so significant to the maintenance of black culture in the city of Louisville that during the aftermath of the 1968 uprising that occurred at $28^{\text {th }}$ and Greenwood, members of the community guarded the store to ensure that no one damaged the façade or looted the merchandise ${ }^{95}$ Opening the Corner of Jazz in Louisville's West End is an example of how a relatively small act can carry with it a sense of politicization. By bringing a store that so unashamedly celebrates blackness, Clay was making a statement, and the West End community responded in turn by protecting what was theirs. Although the shop did not survive long after the uprising due to depleted business, it stands as a testament to the

\footnotetext{
${ }^{93}$ Ken Clay, Oral History Interview with Wes Cunningham, Louisville, KY, November 18, 2015. Clay was a former employee at the Urban League in Louisville and one of the founders of Renaissance Development Corporation where they "put together a number of different programs, one in housing, one in employment, one in economic development and one in the arts... ironically the thing that really caught on was the arts." Although Renaissance was not created until the seventies, Clay was active in the arts scene much earlier as one of the editors of the 1966 Arts and Talent Festival Literary Digest, alongside Bob Douglas and Anne Braden, and as a poet in the Festival the same year; Fact Sheet for the 1966 West End Arts and Talent Festival, 1966, box 3, file 18, WECC Papers; Tentative Program for the 1966 West End Arts and Talent Festival, 1966, box 3, file 18, WECC Papers. ${ }^{94}$ Clay, Interview with Wes Cunningham. ${ }^{95}$ Ibid.
} 
importance of black culture to the black community as well as to the political implications of something that would not traditionally be seen as a political act. 


\section{ARTISTS, THEIR ART AND SOCIAL CONSCIOUSNESS-RAISING IN LOUISVILLE}

One of the constant assertions among the visual artists was that they were not going to let their art be defined by the skin color of the individual who created it. Douglas stated that because of where Gallery Enterprises was located and the social climate of the sixties, "circumstances made us look more like what the Black Arts Movement did on purpose. ${ }^{.96}$ Additionally he recalled that at the Workshop "we were politically conscious" but in regards to the "protest artists...we would have none of that.." ${ }^{97}$ Even so, Douglas conceded that that art "promotes the culture from which it springs," and Sam Gilliam stated that "the more you live, the more art and life, esthetics and politics tend to merge." ${ }^{98}$ Merv Aubespin, fellow Workshop artist, acknowledged that "much of the art we did were statements that related to the black freedom struggle... whether they were abstract or realistic." ${ }^{\prime 99}$ The artists in Louisville referred to the blatantly political artists using terms like "activist artists" or "protest artists" as a way to distance themselves. Most of the key players in Louisville received degrees in art and many of them were pursuing a career in their field. They looked down at the so-called activist art as inferior

\footnotetext{
${ }^{96}$ Douglas Interview

97 Ibid.

${ }^{98}$ Douglas Interview; Quote from Elsa Honig Fine, The Afro-Amerifcan Artist: A Search for Identity (New York: Holt, Rinehart and Winston, 1973), 225-226.

${ }^{99}$ Aubespin Interview.
} 
forms of expression compared to what they were able to create with professional training. Their art was born out of experience and environment, not activism. But, since their experience was burdened with the struggle for racial justice, their art, though not always intentionally political, still challenged the status quo. This places the Louisville artists at a different spot on the political spectrum, because even when they were not overtly confronting social policy through their work, by simply creating and promoting a positive black identity they were making a political statement.

To fully understand the unintentional politicization of some of the art being produced, one must first look at the backgrounds of some of the organizations' participants. Sam Gilliam, one of the founding members of Gallery Enterprises, frequently spoke about the possibility for black artists to "change the racial discrimination against them." 100 While Gilliam was a graduate student he "participated in all forms of activism from sit-ins to pickets for the purpose of ending segregation in public accommodations" but as he grew older he withdrew from direct activism and said that "art was as important as politics." ${ }^{\text {"101 }}$ Bob Douglas was a "community organizer at the beginning of the war on poverty" as well as urban renewal relocation officer where he saw "how people were being manipulated" in the city of Louisville. ${ }^{102}$ Merv Aubespin had been a longtime direct-action activist in the Civil Rights Movement through pickets and eventually became the first African American reporter at the Courier-Journal,

\footnotetext{
100 Douglas, "The History of Louisville's African American Artists Since 1958." ${ }^{101}$ Jonathan P. Binstock, "Sam Gilliam: The Making of a Career, 1962-1973," (PhD. Diss., The University of Michigan, 2000).; Vivien Raynoy, "The Art of Survival (and Vice Versa): Four Young Artists Illustrate the Shift from Bohemia to Bureaucracy," New York Times Magazine, February 17, 1974, 52.

102 Douglas Interview
} 
Louisville's premier newspaper. ${ }^{103}$ Ed Hamilton remembers the first time that he ever picketed was with the Workshop when they were intentionally left out of the Potpourri of the Arts, a supposed city wide art event, because of their race. ${ }^{104}$ So although the organizations maintained that they were made up of non-activist artists, their political and social consciousness was evident in their personal lives, which unavoidably came out in their work.

\section{Bob Thompson}

Although not all of the members of these organizations were political in their personal lives, many of them exhibited signs of politicization in their artwork. Bob Thompson, the most successful artist to emerge from Gallery Enterprises, left Louisville for New York in $1959 .{ }^{105}$ One scholar suggests that "his move to New York was an act of self-assertion and self-determination through which he positioned himself among a group of similarly minded artists among whom he flourished and gained the recognition he desired." ${ }^{106}$ Thompson's art has several examples of subtle politicization and his critique of racism. Some of Thompson's contemporaries recall his use of vibrant colors as his assessment of the color lines in America ${ }^{107} \mathrm{He}$ also frequently used a style of

\footnotetext{
${ }^{103}$ Aubespin, Interview with Wes Cunningham.

${ }^{104}$ Hamilton, Interview with Wes Cunningham.

105 The sources are conflicting regarding the year that he left Louisville. The Kentucky African American Encyclopedia entrance has the year he leaves as 1958, but in Thelma Golden's Bob Thompson (New York: Whitney Museum of American Art in Association with University of California Press (Berkeley, CA), 1998) he leaves sometime after his exhibition in Louisville in the winter of 1959 and in Douglas', "The History of Louisville's African American Artists since 1958," he is in Louisville to participate in the clothesline art show in the fall of 1959.

106 Slade Stumbo, "Seeking Bob Thompson: dialogue/object," (M.A. Thesis, University of Louisville, 2013).

107 Ibid. Stumbo quotes both Mimi Gross and Hattie Jones and their thoughts on Thompson's use of color.
} 
appropriation where he took classic works of art and reproduced them using his own vivid, bold and colorful style. Some artists argued that he obviously had no qualms with the racial lines because he was replicating works done by white Europeans, which in turn "made white people comfortable," while others contended that by appropriating these classics, he was dismissing the "notion of inferiority," showing that even a black man can have a spot among the white classics. ${ }^{108}$ By boldly asserting his place next to some of the Renaissance's heroes, Thompson showed his understanding and respect for their art while he made it his own. Like artists from the Harlem Renaissance, he refused to be labeled as lesser because he was a black man, instead he positioned "himself as both student and heir of the Old Masters." 109

\section{Sam Gilliam}

Sam Gilliam, another of Gallery Enterprises' alumni who went on to fame, similarly challenged the notion of racial confinement with his art. Gilliam was quoted saying the more mature an artist becomes and the more comfortable one gets in their role as an artist, then they "feel less afraid when someone says, 'I can't believe these paintings express your blackness." ${ }^{, 10}$ One of Sam Gilliam's major interventions into the field of painting was his unique style of displaying his canvases, a method which highlighted abstract color work and was common among those associated with the Washington Color

\footnotetext{
108 Ibid. Such examples can be seen by comparing Thompson's The Golden Ass (1963) with Francisco de Goya's Capricho 42 (Thou Who Cannot) (1799), as well as Thompson's Salome's Dance or The Feast of Herod (1962) with Fra Angelico's The Feast of Herod (c. $15^{\text {th }}$ century).

109 Ibid.

${ }^{110}$ Binstock, "Sam Gilliam." Quote of Gilliam comes from Elsa Honig Fine, The AfroAmerifcan Artist: A Search for Identity (New York: Holt, Rinehart and Winston, 1973), 225-226.
} 
School. ${ }^{111}$ These free-form pieces, often referred to as 'drape' paintings, did away with the stretchers that typically were used to display canvases, where instead Gilliam exhibited them "hung in monumental billows...twisted over landscapes out of doors...unfurled from buildings or strung across trees."112 One scholar makes the claim that African American artists were drawn to the abstract art form because it allowed them to exhibit "individual and artistic freedom to the art world's racial front." ${ }^{, 113}$ In this manner, Gilliam's free-form ‘drape' paintings demonstrated not only abstract freedom, but freedom from the confines of frames, stretchers or supports. Some of Gilliam's art covered sides of buildings, as can be seen with his work Seahorses that covered two exterior walls at the Philadelphia Museum of Art, while others hung from ceilings, like Light Depth. ${ }^{114}$ Not only did Gilliam challenge the conformity of framed and mounted art, he also invited patrons to "walk under and through his creations" giving the audience a chance to fully be "enveloped by art." ${ }^{115}$ In doing this Gilliam demonstrated both his aversion to constraint by making a piece so large in scale that it covered a building and his distaste for superiority by creating a free-form canvas that invited the public to be a

${ }^{111}$ Sharon F. Patton, African-American Art (Oxford: Oxford University Press, 1998), 218221. The Washington Color School was an art movement from Washington D.C. that sprung out of the Colour-Field painting style.

${ }^{112}$ Red \& Black to " $D$ ": Paintings by Sam Gilliam (New York: The Studio Museum in Harlem, November 14, 1982 - February 27, 1983). Published in conjunction with the exhibition of the same name, shown at the Studio Museum in Harlem. Quote taken from "Sam Gilliam: Journey Toward Red, Black and 'D'," by Dr. Mary Schmidt Campbell. ${ }^{113}$ Powell, Black Art, 102.

${ }^{114}$ Sam Gilliam Indoor and Outdoor Paintings 1967-1978 (Amherst, MA: University Gallery, University of Massachusetts/Amherst, September 16 - November 5, 1978); Sam Gilliam: Folded and Hinged (Baton Rouge, LA and Laurel, MS: Louisiana Art \& Science Museum and Lauren Rogers Museum of Art, 2004) Published in conjunction with the exhibition of the same name, shown at the Louisiana Art \& Science Museum, February 28 - April 18, 2004, and at the Lauren Rogers Museum of Art, May 15, 2004 - July 3 , 2004.

${ }^{115}$ Sam Gilliam: Folded and Hinged. 
part of. His announcement of freedom and inclusion through his art demonstrated the underlying politicization that occurred in many of these artists' work.

\section{Bob Douglas}

One of the founding fathers of both Gallery Enterprises and the Louisville Art Workshop, Bob Douglas, was active in social justice in his personal life but rejected the idea of being a protest artist, or someone he viewed as creating controversial artwork solely for the purpose of making a statement, not for art's sake. Douglas even wrote when referring to protest artists that "the wors[t] crafted art, usually by those with less professional training were the ones who got the most press." ${ }^{\text {"16 }}$ His artwork, however, often demonstrates social consciousness and powerful critique of America as a white supremacist nation. One such example of Dr. Douglas' artistic criticism, and subsequent celebration of African American beauty, culture and history, can be seen in his large collection entitled "Shades of Earth Mother."117 Douglas sought to challenge the propensity of popular culture and traditional art to only display white women as attractive, thus leading black women to not believe themselves to be beautiful. This series, created over a ten year period, consists of naked black women sitting alone in a room with the purpose to "lessen any suggestion of sexual intentions" and focus strictly on the varying beauty of the African American woman. ${ }^{118}$ To show the intricacies of his artistic process, the collection is sixty pieces made up of three variations of twenty separate women; the rough sketch, an almost life-sized oil painting and smaller abstract versions. Consistent with his "homage to African women," Douglas acknowledged that

\footnotetext{
116 Douglas, "The History of African American Artists in Louisville since 1958."

117 Bob Douglas, "Earth Mother Series: Shades of Earth Mother," Bob Douglas, artist/scholar, accessed on July 5, 2016, http://bobdouglasart.com/?page_id=334. 118 Ibid.
} 
women were historically held in high esteem in African tradition, a feeling that has become lost among many people in today's society. ${ }^{119}$ Echoing the cries of "Black is Beautiful," he wrote that the black community must display "positive attitudes and respect" for their women. ${ }^{120}$ Furthermore, he argued that "the tentacles of white power...have wormed their way into our neurons" by perpetuating such clichés as "blonds have more fun" and depicting white women as goddesses. ${ }^{121}$ By celebrating the diverse beauty of black women in a society that neglects them, Dr. Douglas encouraged self-esteem and pride among the black community.

\section{G.C. Coxe}

G.C. Coxe, a man frequently referred to as the "dean" of the Louisville black arts community, had a presence there in one way or another for over seventy years. ${ }^{122}$ During his years of participation he touched countless lives through his art, instruction, and mentorship and was a "general source of inspiration" to many. ${ }^{123}$ Coxe was a very talented visual artist, but he also excelled in literary art. It was using this medium that he criticized urban renewal with a beautiful sense of despair and a feeling of exclusion,

\footnotetext{
119 Ibid.

120 Ibid.

121 Ibid.

122 Referred to as the Dean in, Diane Heilenman, "Unconventional Hero: G.C. Coxe Exhibit at U of L Pays Tribute to Artist Whose Risk-Taking Still Inspires Others," The Courier-Journal, November 12, 1995, 9; Rochelle Riley, "Legacy isn't in his work but how he Nurtured," The Courier-Journal, July 27, 1999; and in a quote by Ed Hamilton from, Gloucester Caliman Coxe: A Retrospective; In the Louisville art community Coxe was instrumental in the forming of the Bourgard School of Art and Music, he was the first graduate of the University of Louisville Art School, he was one of the first African Americans to teach art in public schools in the city and he was a key player in the formation of both Gallery Enterprises and the Louisville Art Workshop.

${ }^{123}$ In Gloucester Caliman Coxe: A Retrospective, many of his peers, students and friends speak on their admiration of him. The quote is from Bob Carter and is located in that exhibit program.
} 
while lamenting the horrors of substandard living in a segregated city in his piece Moved

West: barriers.

Jobs were scarce, virginity a bore and prostitution the only work that had no racial

Groans of bulldozers, pushing, scraping, loading brick-rubble and the past of those who once lived there, into trucks that rumbled away and spilled that life on dump heaps...

Move West...

God dammit, move west.

I walk.

Past proud old houses, frame, brick and stucco; one family dwellings where now many bulge, over-crowded tents in these hot August days.

Past Churches...

"Forgive us our trespasses..."

White disciples preaching from white pulpits to white pews about white "gods"...

"Give us this day our daily 'bread'..."

...One day I will make a prayer of my own. I will run along your boundaries Urban Renewal and this river's banks - this camp..., Storms will be my hymns and rains. And I will shout my prayers across these muddied banks, in cadences loud enough for history...

Public Accommodations...?

Open housing...?

Integration?

Integration?

Past and future to hear me - Golgotha, Holy Cities, Holy Ghosts and statues of Liberty. Ancients of ancients will consent with me. And YOU in your white-plushed pews, (built for this Christian "business"), will hear me also.

"Hallowed be thy name..."

Forgive me? No. Forgive YOUR Gods that I am not man of YOUR image. Forgive that in that spittled-dust, with which He "jested," He "willed" that I walk black upon this city's Hop-Scotched, Urban re-newed streets...

"Thy Kingdom Come...Thy Kingdom Come..."

And when my shoutings and demonstrations against YOUR pale, unfeeling "Gods" is exhausted - storms passed, I will be done with prayer making. One with YOUR commandments and YOUR conventions and the authors of them...Done with pale Holy Ghosts, pale Fathers and Pale Sons.

"This bitter earth...

I will be done with progresses...

What fruit it bears...

Committed by machines alone...

Someone may answer my call..." 
Confine me with Christian compassion instead of this river's banks; moral "Renewal" instead of "Urban Renewal" and I will not have to "Move West."124

This piece demonstrates how high quality "high" culture such as poetry or prose could take a social justice stand rooted in community. Moreover, the piece was published by an integrated organization to a wide public, and thus mixed race, audience as part of an integrated art festival. Coxe wanted to present this message of dissatisfaction with Louisville to a gathering that was attended not only by people of the black community, but by those from around the city. Whereas some of the art being created by other Louisville artists was not as overtly political, and thus appear in a different place on the political spectrum, Coxe's piece was much more explicit on policy and therefore more politicized. This shows that while the organizations as a whole appeared to be less active on the surface, some of the members were producing work that was much more blatant, thus demonstrating the differing levels of politicization.

\section{Anna Bond}

Anna Bond was a long-time member of the Louisville Art Workshop and played an integral role in its survival by sharing her home with the work and gallery space. Bond was a visual artist, a musician and a brilliant poet. In her poem, $A$ Kind of Blueness, she engaged the idea of blackness and the beauty and positivity that can surround it:

Hear all the good mother things

The gold horn wrings

From blueness?

I hear them

And I become sad

At first.

I bear them

${ }^{124}$ G. Caliman Coxe, "Moved West," in West End Community Council Arts and Talents Festival 1967 Literary Digest: MOVE WEST for...the Things we Share (Louisville: West End Community Council, 1967), 27-30. 
And I become glad

And thirst for

The key to blackness

And me.

Hear all the black brother sounds

The blue horn ground

To "you-ness"?

I hear them

And down I become

From where I had been.

I feel them

And up I become

To there! Aware then,

I care about me,

And blackness.

I see. $^{125}$

Bond emphasized the importance of identity and blackness in a world where there are so many other things to overcome. She promoted the idea that "Black is Beautiful" and that being black means you don't have to abandon your identity, but instead discover it, be proud of it, and pass it on. These two pieces shine light on two major aspects of the consciousness-raising efforts in Louisville: intensely voicing one's discontent with the racist world and passionately reaffirming the confidence of blackness, and both were exhibited in an integrated forum. Anna Bond's poem, though not overtly challenging policy as exhibited in Moved West, establishes another degree of politicization. By promoting blackness, she was challenging the status quo of white cultural supremacy and encouraging black pride, all of which made a statement.

${ }^{125}$ Anna Mulligan Bond, "A Kind of Blueness," in West End Community Council Arts and Talents Festival 1968 Literary Digest: Dreams Reality and Renaissance (Louisville: West End Community Council, 1968), 26. 


\section{Fred Bond}

One of the founding members of Gallery Enterprises and key individual responsible for the establishment of the Louisville Art Workshop, Fred Bond was a lifelong supporter of the arts in the black community. By the time Gallery Enterprises was founded, of which Bond was the chairman, he had been organizing groups around arts and culture for several years. ${ }^{126}$ Additionally, Bond's family had a history of working in politics and activism; his grandfather was a former slave and director of the Kentucky Commission on Interracial Cooperation and his cousin was politician and activist Julian Bond. ${ }^{127}$ Bond, who was a ceramicist who often "had to paint to get credibility" for his ceramics, was also lyrically talented. ${ }^{128}$ For the 1966 WECC Arts and Talents Festival Literary Digest he wrote "1966 American Ghettos" in the form of a fake advertisement to discuss the inadequacies of ghettos in the black community:

"My pimples and blackheads cleared up 100\% since we got our new 1966 Ghetto."

\section{Ghettoes are FUN!!!}

WHAT DOES IT DO? Any number of things. It's really a marvel. For one thing, your New 1966 American Ghetto can make Negro remov.......that is URBAN RENEWAL, possible. U.R. (urban renewal) as you know restores that life-giving, healthful vitality to your city - makes it feel good again...

${ }^{126}$ Senta Bier, “Art in Kentuckiana: Two Exhibits at Bellarmine Show Much Impressive Work," The Courier-Journal, April 24, 1960, 117; Sometime in the late forties or early fifties, Bond, along with "Black Beat poet/painter/world citizen Ted Joans," and Horace Bond, his uncle, "founded the International Bebop Society, a group that met each week at a local YMCA to dissect and savor the latest jazz recordings." quotes are from Wilson, "Garden of Music: the Art and Life of Bob Thompson," 36.

127 Mary S. Donovan and D. Patricia Wagner, Staff writers of the Kentucky Commission on Human Rights, Kentucky's Black Heritage: The Role of the Black People in the History of Kentucky from Pioneer Days to the Present (Frankfort, KY: Commonwealth of Kentucky, Kentucky Commission on Human Rights, 1971), 70, 139; Smith, McDaniel, and Hardin, The Kentucky African American Encyclopedia, 54

${ }^{128}$ McKay, "Bonding Together." 
Energy Producer: Your New Ghetto is guaranteed to generate a strong two-way current of hate and suspicion which energizes your entire system...

In answer to the vicious rumor that Ghettoes occasionally burn or catch fire, our New 1966 American Ghettoes come with the lifetime guarantee which states that: In the event of a fire or any failure of your Ghetto, a local, state or even national maintenance crew will be standing by to keep it in working order. We stake our name, our tradition on it. (This should not be interpreted to mean that American Ghettoes are fireproof.) --This is a paid announcement-- ${ }^{129}$

Fred Bond's approach to the ghetto problem that occurred in many poorer black communities is intriguing. Not only did it address the very real problems that were happening in Louisville's West End, but it simultaneously condemned the people in power by sarcastically imitating their brand of lying to the public. While not all of Bond's art was meant to be political, this piece, with its blatant implications and mocking tone, was clearly his way of taking a stand against the injustices in the city, and therefore a political act. His cry against the mistreatment of his community is a motivating and inspirational piece of literary art. The previous three pieces were all published in a literary digest meant to circulate the city, which could explain the more direct form of politicization of the subject matter. While the goal of the organizations from which these artists sprung remained intent on not being explicitly political, these pieces show how members themselves can create art with differing intensities of politicization and thus appearing in fluctuating places of the spectrum.

Unlike Gallery Enterprises and the Louisville Art Workshop, the West Side Players were very up front about their goal of advocating for social and racial change through their work. One such example was the production of a play titled "The Death of

\footnotetext{
${ }^{129}$ Fred F. Bond, "no title," in West End Community Council 1966 Literary Digest: Living
} in a New World (Louisville: West End Community Council, 1966). 
Bessie Smith" by Edward Albee. This play is about the death of a jazz singer from the early twentieth century who died as a result of being refused care from two separate Memphis hospitals. ${ }^{130}$ Similarly, George Sklar's "And People All Around" is "based on the murders of the three civil rights workers in Mississippi." ${ }^{, 131}$ In one short skit they performed a man walked out to face the audience and simply said;

God made the nigger,

And he made him in the night

And in his hurry

He forgot to paint him white ${ }^{132}$

Famous for their unapologetic criticisms of a racist America, the West Side Players presented "radio commercials, recorded to be broadcast in the Louisville area on public service time." ${ }^{, 133}$ One of these, which used humor to get the point across was titled "The Headache":

Black woman: $\quad$ I like this house, I think I'll buy it.

White man: $\quad$ You know it's very expensive.

Black woman: $\quad$ I don't care, I have the money, and I want to buy it.

White man: $\quad$ It's $\$ 20,000$.

Black woman: $\quad$ I still want to buy it.

White man: $\quad$ You know you'll be the only Negro family in the neighborhood.

Black woman: I don't mind integrating. I like the house and I want to buy it...Say, what's that little green bottle? Do you have a headache? White man: $\quad$ Yes. You've given me an extremist's headache. ${ }^{134}$

Here they used comedy to draw attention to the struggles over open-housing in the city but did so in a funny way. This approach was used to keep the audience engaged and

130 Jean Dietrich, "West Siders' 'Bessie Smith'," The Courier Journal, May 30, 1971, E1:6.

131 Joan Kay, "Shawnee Park Bills Fifth Festival," The Courier-Journal, August 21, 1969, 18.

132 Woolsey, "Say it with Theater."

133 Office of Economic Opportunity, unnamed report. ${ }^{134}$ Ibid. 
supplement some of the more abrasive material that they were producing. With advocating for racial equality and encouraging discussion around racial issues as main goals of the West Side Players, they logically fall toward the more overtly political range of the spectrum. Although they were originally created to provide arts and education to African American children, the subject matter that they frequently and adamantly engaged with made their productions more politicized. 


\section{CONCLUSION}

Black Art has always had very different ambitions and motivations. While the desire to create was at the heart of the artist, for an African American producing art in the mid-twentieth century, there were different forces speaking to them. As a result of this, the artwork created by the African American artist found itself existing somewhere along an ever-changing spectrum of politicization. In some cases, the artist was blatant about their desire to challenge social norms through their artwork while in others, subtlety was used. In every case, as a black artist in the heart of the black freedom struggle, by simply creating art they were making a statement that defied the notion that white people were superior. Beginning in the early twentieth century with the NAACP's cultural campaigns and the Harlem Renaissance's intellectuals, through the Black Arts Movement, and continuing today, this spectrum of politicization changes based on what would be considered challenging the status quo. Because of this constant change, black art had varying implications which made claiming aversion to political art in the sixties an impracticality for black artists.

Members of the Louisville black arts scene frequently echoed cries made by black intellectuals from national art movements. Merv Aubespin said that the segregated world “always put emphasis on what we can't do or be and so we felt strongly it was not only 
right but it was our duty to show what we could be and do." ${ }^{355}$ Bob Douglas said that "I wanted my work to celebrate the achievements of the life of black people...I wanted people to be sure that a black artist did that." ${ }^{, 136}$ The production of black art was in itself challenging the white supremacist cultural atmosphere in America, but beyond that, bringing a community together through consciousness raising was crucial for the advancement of African Americans and were politicized acts. "As an artist...it was more a case of expressing yourself, imparting beauty, making some kind of artistic statement...it was not to be considered apart from other people [or] better than other people." ${ }^{\prime 137}$ Although the African American art community in Louisville at the time was diverse in its methods, beliefs and goals, it shared the idea that art was meant to bring people together, not divide.

In Louisville, the cultural manifestation of social justice movements was very visible. Louisville social justice organizations often maintained integrated memberships and were deliberate about promoting cooperation between varying movements and organizations. The success of Louisville's movement building led the local black arts scene to explicitly organize around the arts. By placing the focus of these art organizations on celebrating the black identity, creating a community of artists, and building careers around the arts, they were able to appeal to professionally trained artists, which in turn led to the success of many of their members. Several participants went on to national fame as artists including Bob Thompson, Sam Gilliam, Ed Hamilton and Bob

\footnotetext{
${ }^{135}$ Aubespin, Interview with Wes Cunningham.

${ }^{136}$ Douglas, Interview with Wes Cunningham.

${ }^{137}$ Kunnecke, Interview with Wes Cunningham.
} 
Carter, who also achieved success as a professor. ${ }^{138}$ In addition to Carter, some of the alumni went on to teach at institutions of higher education like Bob Douglas at the University of Louisville and Eugenia Dunn at the Philander Smith College in Little Rock, Arkansas. ${ }^{139}$ Furthermore, former members of these organizations went on to work in museum settings like Kenneth Victor Young and Fred Bond. The fact that Louisville offered several opportunities for African Americans to study art in the mid-twentieth century was also key to the achievements of the artists. While the members of these groups were individually concerned with the political and social disparities that were facing black Americans, as can be seen through the art they were producing, the organizations themselves were not burdened with addressing these issues. This allowed for the groups in Louisville to provide a nurturing community of artists to which the success of the members can be attributed. The inclusionary nature of these organizations and the events that they held enabled for the artists to gain the self-confidence necessary to succeed in an integrated world.

Identity building was always paramount to the goals associated with the various arts organizations in Louisville, as was integration. Although many of the local artists would deny being labeled activist artists, they nonetheless sought to further the fight for social justice within the city, both by raising awareness and promoting an inclusive community. Even though intention was not always there, many of the pieces by black artists were seen as political merely because they were created from the black experience, however the very act of creating such pieces was sometimes enough to make a

\footnotetext{
138 "About Us," Robert Carter Studio, accessed August 7, 2016, http://www.robertcarterstudio.com/\#aboutus.

139 Douglas, "The History of Louisville's African American Artists since 1958."
} 
difference. ${ }^{140}$ Although some artists like W.E.B. DuBois and Emory Douglas focused on intentionally producing overtly propagandized art with the hopes of promoting change, many of the artists in Louisville simply created work that was informed by their experiences as African Americans and as a result their work had political connotations. ${ }^{141}$ A lot of the art that was being created by the black artists within the Louisville scene had political implications, but their ongoing devotion to community, education and integration were political acts in themselves. One of the long-time goals of the Louisville Art Workshop was "to display to the community its own cultural wealth, that is, in the talents of its citizens, either black or white." ${ }^{142}$ In addition, the influential art that was being created and the productions that blatantly addressed the inequalities in America were being done by integrated art organizations and theater troupes. People throughout Louisville and its surrounding areas participated in, saw or read art that was created by the city's black residents which encouraged them to think about the imbalances within the city and recognize the West End's citizens as equal. When one goes back to analyze the art and the influence that these visionary artists had on Louisville's history with a social justice and community-building lens, one recognizes the importance of culture to the black identity. Their presence in the community strengthened it. The art that they created signaled a level of black intellectualism that was impossible to deny.

\footnotetext{
${ }^{140}$ Hamilton, Interview with Wes Cunningham. Mr. Hamilton says that although most of his public art centers on the black freedom struggle and many of its main characters that was not by design. He instead competed for the contract to do each individual sculpture and in no way thought that this is what he would end up doing. He just wanted to sculpt.

${ }^{141}$ W.E.B. DuBois, "Criteria of Negro Art." DuBois said "I stand in utter shamelessness and say that whatever art I have for writing has been used always for propaganda for gaining the right of black folk to love and enjoy." Douglas, Black Panther. 142 "Workshop Objectives in Assisting the West End Community Council in the 1967 Arts and Talents Festival," 1967, in box 3, folder 18, WECC Papers.
} 
It is necessary to study organizations of black artists during the long civil rights movement who were not explicitly operating with political intentions. There were, however, definite political implications among these groups. Just by enduring and creating during a tumultuous time in the country's history was a political act in itself and that many of the artists were individually challenging race relations, all of which places them on the political spectrum of the time. Analyzing these organizations allows one to gain insight into what role these art groups were playing in their communities, whether they were art communities, the black community or a geographic neighborhoods. In Louisville, organizations like Gallery Enterprises, the Louisville Art Workshop, and the West Side Players represent an interesting example of groups that were not explicitly engaged in the Civil Rights Movement, yet who addressed politicized issues through their art and their actions. 


\section{REFERENCES}

Allen, Elmer Lucille. "Biography of Elmer Lucille Allen.” Emailed to Wes Cunningham on April 2, 2016.

Aubespin, Mervin, Kenneth Clay and J. Blaine Hudson. Two Centuries of Black Louisville: A Photographic History. Louisville: Butler Books, 2011.

Banner-Haley, Charles T. The Fruits of Integration: Black Middle-Class Ideology and Culture, 1960-1990. Jackson, MS: University Press of Mississippi, 1994.

Bier, Senta. "Art in Kentuckiana: Two Exhibits at Bellarmine Show Much Impressive Work.” The Courier-Journal. April 24, 1960.

Binstock, Jonathan P. "Sam Gilliam: The Making of a Career, 1962-1973.” PhD diss., The University of Michigan, 2000.

"Black Artists Note Falling Barriers." The Courier-Journal \& Times. March 16, 1975.

Bond, Fred F. and David M. Collins. "The Festival's Literary Digest." Letter to the editor. The Courier-Journal. October 11, 1967.

Booker, M. Keith, ed. Encyclopedia of Literature and Politics: Censorship, Revolution, and Writing, Volume III: S-Z. Westport, CT: Greenwood Press, 2005.

Bracey Jr., John H., Sonia Sanchez, and James Smethurst eds. SOS - Calling All Black People: A Black Arts Movement Reader. Amherst, MA: University of Massachusetts Press, 2014.

Collins, Lisa Gail. "The Art of Transformation: Parallels in the Black Arts and Feminist Art Movements." In New Thoughts on the Black Arts Movement, edited by Lisa Gail Collins and Margo Natalie Crawford, 273-296. New Brunswick, NJ: Rutgers University Press, 2008.

Crumpton, Edwin T. "West End Art Festival." Letter to the editor. The CourierJournal. 1967. 
Dietrich, Jean. "West Siders' 'Bessie Smith'.” The Courier Journal. May 30, 1971.

Donovan, Mary S. and D. Patricia Wagner, Staff Writers of the Kentucky Commission on Human Rights. Kentucky's Black Heritage: The Role of the Black People in the History of Kentucky from Pioneer Days to the Present. Frankfort, KY: Commonwealth of Kentucky, Kentucky Commission on Human Rights, 1971.

Douglas, Bob. "Earth Mother Series: Shades of Earth Mother." Bob Douglas, artist/scholar, accessed on July 5, 2016. http://bobdouglasart.com/?page_id=334.

Douglas, Bob. “The History of Louisville's African American Artists since 1958: The Louisville Art Workshop: An Evolution of Two Generations of African American Artists.” Bob Douglas, artist/scholar. July 16, 2013. http://bobdouglasart.com/?p=911.

Douglas, Robert L. Resistance, Insurgence and Identity: The Art of Mari Evans, Nelson Stevens and the Black Arts Movement. Trenton, NJ: Africa World Press, 2008.

Douglas, Emory. Black Panther: The Revolutionary Art of Emory Douglas. New York: Rizzoli Publications, 2007.

Duberman, Martin. In White America: A Documentary Play. New York: Samuel French, Inc., 1964. Accessed May 23, 2016. https://books.google.com/books?id=8Uv7z7yWCjMC\&printsec=frontcov $\mathrm{er} \# \mathrm{v}=$ onepage $\& \mathrm{q} \& \mathrm{f}=$ false.

DuBois, W.E.B. "The Criteria of Negro Art." In The Harlem Renaissance: A Brief History with Documents, edited by Jeffrey B. Ferguson, 160-169. Boston: Bedford/St. Martin's, 2008.

Elder III, Lonne. "Ceremonies in Dark Old Men." Performed by the West Side Players, May $12^{\text {th }}$ and $13^{\text {th }}, 1972$, at The Women's Club, Louisville, KY, Sponsored by Kentucky Arts Commission, the Greater Louisville Fund for the Arts, and National Endowment for the Arts. Performance program.

Ferguson, Jeffrey B. The Harlem Renaissance: A Brief History with Documents. Boston: Bedford/St. Martin's, 2008.

Fine, Elsa Honig. The Afro-Amerifcan Artist: A Search for Identity. New York: Hole, Rinehart and Winston, 1973. 
Fosl, Catherine. Subversive Southerner: Anne Braden and the Struggle for Racial Justice in the Cold War South. Lexington, KY: University Press of Kentucky, 2006.

Gloucester Caliman Coxe: A Retrospective: Rags and Wires, Sticks and Pantyhose Too. Louisville: Allen R. Hite Art Institute and Pan African Studies Department, College of Arts and Sciences, University of Louisville, November 17 - December 15, 1995. Published in conjunction with the exhibition of the same name, shown at the Morris B. Belknap Jr. Gallery, Dario A. Covi Gallery, Louisville, KY.

Golden, Thelma. Bob Thompson. New York: Whitney Museum of American Art in Association with the University of California Press (Berkeley, CA), 1998.

Hall, Jacquelyn Dowd. "The Long Civil Rights Movement and the Political Uses of the Past." The Journal of American History 91 (2005): 1233-1263.

Hamilton, Ed. The Birth of an Artist: A Journey of Discovery. Louisville: Chicago Spectrum Press, 2006.

Heilenman, Diane. "Unconventional Hero: G.C. Coxe Exhibit at U of L Pays Tribute to Artist Whose Risk-Taking Still Inspires Others." The CourierJournal. November 12, 1995.

Huggins, Nathan Irvin. Harlem Renaissance. New York: Oxford University Press, 1971.

Johnson, James Weldon. The Selected Writings of James Weldon Johnson: Volume II, Social, Political, and Literary Essays. Edited by Sondra Kathryn Wilson. New York: Oxford University Press, 1995.

Joseph, Peniel E. Waiting 'Til the Midnight Hour: A Narrative History of Black Power in America. New York: Henry Holt and Company, 2006.

Karsell, Tom. “Art Show In Central Park: 'They Hold Air,' Housewife-Artist Explains About Use of the Pottery." The Courier-Journal. August 21, 1961.

Kay, Joan. "Shawnee Park Bills Fifth Festival." The Courier-Journal. August 21, 1969.

Kay, Joan. "Speaking of People: Art Workshop show at Actors gives sampling of a year's work." The Courier-Journal. January 10, 1971. 
Kleber, John E. ed. The Encyclopedia of Louisville. Lexington, KY: The University Press of Kentucky, 2001.

K'Meyer, Tracy E. "Building Interracial Democracy: The Civil Rights Movement in Louisville, Kentucky, 1945-1956." In Time Longer Than Rope: A Century of African American Activism, 1850-1950. Edited by Charles M. Payne and Adam Green, 411-439. New York: New York University Press, 2003.

K'Meyer, Tracy E. Civil Rights in the Gateway to the South: Louisville, Kentucky, 1945-1980. Lexington, KY: The University Press of Kentucky, 2009.

K'Meyer, Tracy E. “"The Gateway to the South': Regional Identity and the Louisville Civil Rights Movement." Ohio Valley History, Vol. 4 No. 1 (2004): 43-60.

Lansdale, Sarah. "Kenneth Young Homecoming at Workshop." The CourierJournal. December 14, 1969.

McGinty, David. "Play Pries at Racial Prejudice.” The Louisville Times. N.d. 1969.

McKay, Bob. "Bonding Together.” Cincinnati Magazine. June 1977.

Mesch, Claudia. Art and Politics: A Small History of Art for Social Change since 1945. New York: I.B. Tauris, 2013.

National Register of Historic Places. Wood F. Axton Hall. Louisville, Jefferson County, Kentucky.

Neal, Larry. "The Black Arts Movement." In SOS - Calling All Black People: A Black Arts Movement Reade, edited by John H. Bracey Jr., Sonia Sanchez, and James Smethurst, 55-66. Amherst, MA: University of Massachusetts Press, 2014.

Office of Economic Opportunity. Unnamed report on the West Side Players in Louisville.

Ogbar, Jeffrey O.G. Black Power: Radical Politics and African American Identity. Baltimore: The Johns Hopkins University Press, 2004.

Ongiri, Amy Abugo. Spectacular Blackness: The Cultural Politics of the Black Power Movement and the Search for a Black Aesthetic. Charlottesville, VA: University of Virginia Press, 2010. 
Paintings by G.C. Coxe: 4 Phases. Edited by Fred F. Bond, Curator and Research Assistant. Nashville, TN: Carl Van Vechten Gallery of Fine Arts, Fisk University, January 23 - February 13, 1972. Published in conjunction with the exhibition of the same name, shown at the Carl Van Vechten Gallery of Fine Arts and Fisk University, Nashville, TN.

Patton, Sharon F. African-American Art. Oxford: Oxford University Press, 1998.

Peretti, Burton W. Lift Every Voice: The History of African American Music. Lanham, MD: Rowman and Littlefield Publishers, 2009.

Powell, Richard J. Black Art: A Cultural History. London: Thames \& Hudson Ltd., 2002.

Raynoy, Vivien. "The Art of Survival (and Vice Versa): Four Young Artists Illustrate the Shift from Bohemia to Bureaucracy." New York Times Magazine. February 17, 1974.

Red \& Black to "D": Paintings by Sam Gilliam. New York: The Studio Museum in Harlem, November 14, 1982 - February 27, 1983. Published in conjunction with the exhibition of the same name, shown at the Studio Museum in Harlem.

Reed, T.V. The Art of Protest: Culture and Activism from the Civil Rights Movement to the Streets of Seattle. Minneapolis: University of Minnesota Press, 2005.

Riley, Rochelle. "Legacy isn't in his work but how he Nurtured." The CourierJournal. July 27, 1999.

Robert Carter Studio. “About Us.” Accessed August 8, 2016. http://www.robertcarterstudio.com/\#aboutus.

Sam Gilliam: Folded and Hinged. Baton Rouge, LA and Laurel, MS: Louisiana Art \& Science Museum and Lauren Rogers Museum of Art, 2004. Published in conjunction with the exhibition of the same name, shown at the Louisiana Art \& Science Museum, February 28 - April 18, 2004, and at the Lauren Rogers Museum of Art, May 15, 2004 - July 3, 2004.

Sam Gilliam Indoor and Outdoor Paintings 1967-1978. Amherst, MA: University Gallery, University of Massachusetts/Amherst, September 16 - November 5,1978 ;

Smethurst, James Edward. The Black Arts Movement: Literary Nationalism in the 1960s and 1970s. Chapel Hill: The University of North Carolina Press, 2005. 
Smith, Gerald L., Karen Cotton McDaniel, and John A. Hardin, eds. The Kentucky African American Encyclopedia. Lexington, KY: The University Press of Kentucky, 2015.

Street, Joe. The Culture War in the Civil Rights Movement. Gainesville, FL: University Press of Florida, 2007.

Stumbo, Slade. "Seeking Bob Thompson: dialogue/object." M.A. Thesis. University of Louisville, 2013.

University of Louisville Hite Art Institute. "Undergraduate Scholarships and Funding.” Accessed July 7, 2016. https://louisville.edu/art/scholarshipinformation/scholarships.html.

Van DeBurg, William L. New Day in Babylon: The Black Power Movement and American Culture, 1965-1975. Chicago: The University of Chicago Press, 1992.

West End Community Council Paper, State Historical Society of Wisconsin, Madison.

Woodley, Jenny. Art for Equality: The NAACP's Cultural Campaign for Civil Rights. Lexington, KY: University Press of Kentucky, 2014.

Woolsey, F.W. "Say it with Theater." The Courier-Journal Magazine. January 25, 1970.

\section{INTERVIEWS}

All interviews are by the author.

Allen, Elmer Lucille. April 4, 2016.

Aubespin, Merv. November 9, 2015.

Clay, Ken. November 18, 2015.

Cunningham, Bob. November 13, 2014.

Douglas, Bob. November 12, 2015.

Hamilton, Ed. April 11, 2016.

Kunnecke, Martina Nichols. April 19, 2016. 


\section{CURRICULUM VITA}

NAME:

ADDRESS:

DOB:

EDUCATION

\& TRAINING:
Wesley Sawyer Cunningham

900 N. Pope Lick Rd.

Louisville, Kentucky 40299

Louisville, Kentucky - December 4, 1987

B.A., History

Murray State University

Spring, 2011

M.A., History

University of Louisville

Summer, 2016

Architectural Historian

Amec Foster Wheeler

August, 2016 - Present

Historic Preservation Contract Worker

Louisville Metro Planning and Design Services

July, 2016 - Present

Graduate Teaching Assistant

The University of Louisville

August, 2015 - May, 2016

Research Assistant

The Anne Braden Institute for Social Justice

Research

August, 2015 - July, 2016

Project Leader

The Anne Braden Institute for Social Justice

Research

August, 2015 - December, 2015 
Museum Evaluator

Kentucky Historical Society

June, 2015 - August, 2015

Oral Historian

Kentucky Historical Society

May, 2015 - July, 2015

Special Collections Winter Intern

Kentucky Historical Society

January, 2015 - March, 2015

Summer Intern and Interim Executive Director

Farmington Historic Plantation

May, 2014 - January, 2015

Special Collections and Museum Assistant Filson Historical Society

May, 2014 - September, 2014

Field Archaeologist

Corn Island Archaeology

December, 2010 - November, 2012

PROFESSIONAL SOCIETIES: $\quad$ National Council on Public History (NCPH) 2014 - Present

INVITED PRESENTATIONS: "Uncovering the Forgotten History of Simmons College Axton Hall, the West Louisville Campus" Celebrating the Legacy of Black Louisville January 29-30, 2016, The Kentucky Center for African American Heritage

"The Navy V-12 Program: Saving the Country, Building a University"

Spirit of '45, August 15, 2015, Bowman Field

"Symposium on Adobe Premiere, oral histories, and creating digital stories"

University of Louisville, Spring 2016

"Symposium on the Oral History Metadata Synchronizer (OHMS)

University of Louisville, Fall 2015 